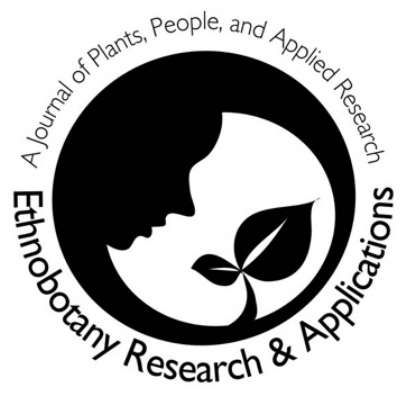

\title{
Ethnomedicinal Survey of Plants used for Management of Inflammatory Diseases in Ringim Local Government, Jigawa State, Nigeria
}

Anas Abba and Abdulrahman Mahmoud Dogara

Correspondence

Anas Abba ${ }^{1}$ and Abdulrahman Mahmoud Dogara ${ }^{2}$

${ }^{1}$ Department of Pharmacognosy and Herbal Medicine, Bayero University Kano, Kano State- Nigeria.

${ }^{2}$ Department of Biology, Faculty of Education, Tishk International University Erbil/Iraq

${ }^{*}$ Corresponding Authors: aabba.phd@buk.edu.ng / abdulrahman.mahmud@tiu.edu.iq

Ethnobotany Research \& Applications 22:47 (2021)

\section{Research}

\begin{abstract}
Background: Physical trauma, unpleasant chemicals, or microbial infections produce inflammation, which is a typical defensive reaction to wounded tissue. It is the body's response to inactivate or eliminate invading pathogens, remove irritants, and prepare tissues for repair. Inflammation is called Kumburi by Hausa tribe of northern Nigeria. Minor or chronic inflammation is considered one of the major diseases affecting people all over the world. According to current estimates, almost 6 million people worldwide suffer from chronic inflammation. Nigeria has an abundance of biodiversity that has largely gone untapped, and it could be a source of new lead compounds for the treatment and control of inflammation. This research was aimed to documents and evaluate the traditional methods used for the management of inflammatory diseases in the Ringim Local Government Area of Jigawa State.
\end{abstract}

Methods: Ethnobotanical study for the medicinal plants that are used in the management of inflammatory diseases were conducted between the periods of May, 2016 - May, 2018 in Ringim Local Government Area of Jigawa State. Indigenous medicinal plant information was gathered utilizing a scientifically organized questionnaire with the aid of respondents who were considered in traditional/alternative medicine. Purposive sampling was used.

Results: .In total, 47 medicinal plant species were discovered in the study, which was divided into 25 families and used for the treatment and management of inflammation. To avoid any misidentification, species having the same local name were not collected. With ten species, Leguminosae is the most common family. Only species with a minimum of 0.6 relative frequency of citations were reported quantitatively. The study recorded the highest used value at (0.07), the relative frequency of citation (0.9), and the fidelity level $90 \%$.

Conclusion: Plants with medicinal potential are still the only way forward, as their acceptance and recognition spread over the globe. The current study found that residents of the Ringim local government had a good understanding of the therapeutic plant. Despite the advancement of modern medicine, locals continue to rely on traditional herbs for health treatment.

Keywords: Ethnomedicine, Ethnopharmacology, Inflammation, Management, Plants, survey 


\section{Background}

The release of chemical mediators from wounded tissues and migratory cells causes inflammation in most cases (Rankin, 2004). Chemical mediators such as histamine, serotonin, lipids such as prostaglandins, and tiny peptides such as kinins are all particular and rely on the type of inflammatory process (Abdulkhaleq et al. 2018). Physical trauma, unpleasant chemicals, or microbial infections produce inflammation, which is a typical defensive reaction to wounded tissue (Divya et al. 2016). It is the body's response to inactivate or eliminate invading pathogens, remove irritants, and prepare tissues for repair (Pungle et al. 2018). Inflammation is the body's natural defense system. The immune system recognizes and eliminates harmful and foreign stimuli, helping the body to heal (Pahwa et al. 2020). It is the world's leading cause of death (Fernandes et al. 2018; Sangiovanni et al. 2020; Pahwa et al. 2020). Several drugs are used to treat inflammatory illnesses, but long-term treatment can cause gastrointestinal discomfort, bone marrow depression, and water and salt retention (Jadav et al. 2010). Herbal remedies are becoming increasingly popular in recent years because herbal medications have no or minimal negative effects (Abdulrahman et al. 2018; Mahmoud et al. 2020). Plants continue to be a novel source of structurally essential molecules that contribute to the development of innovative medications, as traditional medicine expands to newer horizons. (Anilkumar, 2010). Minor or chronic inflammation is considered one of the major diseases affecting people all over the world. According to current estimates, almost 6 million people worldwide suffer from chronic inflammation (Namsa et al. 2009). Nigeria's flora is vast and rich, with many medicinal plants used by natives for therapeutic purposes (Sonibare Abegunde, 2012). Plants are known for containing a large number of chemical constituents. Nigeria has an abundance of biodiversity that has largely gone untapped, and it could be a source of new lead compounds for the treatment and control of inflammation (Durugbo et al. 2012). Simultaneously, the use of ethnobotanical surveys to gather and document indigenous medicinal plant knowledge is envisioned as a key tool for discovering potential active principles from the plant material in the local community (Mahmoud et al. 2020). The goal of this research was to gather and publish information on plants that have traditionally been utilized in Ringim to treat and control inflammation.

\section{Materials and Methods \\ Study Area}

Ethnobotanical study was carried out in Ringim Local Government Area which covered Ringim in Ringim district, Chai-chai in Chai-chai district, Gamoji in Sankara district, and Kyarama in Dabi district. Ringim local government has a population of 192,024 as of 2006 with an area of 1,057 km². The local government has the latitude and longitude at $12^{\circ} 9.09 \mathrm{~N} 9^{\circ} 9.73 \mathrm{E}$ respectively (Figure 1). They are mainly Hausa and Fulani (nomadic). Their major occupations are farming, animal rearing, fishing, and hunting. The area is characterized mainly by two seasons dry (October-May) and wet (June-September) yearly but sometimes varies it depend (Zakariya et al. 2021).

\section{Sampling and Interview sessions}

The methods of non-random probability and expert sampling method were employed in this study (Awang et al. 2018). The people interviewed were principally a constitution of Traditional Medicine Practitioners or herbalist or traditional healers, elderly people with the claim of traditional plant knowledge, apprentices, and traditional birth attendants. The interview was conducted in local languages with an in-depth questionnaire as a guide.

\section{Procedure for Data Collection}

The data for this research were obtained from direct interviews with the local people, conducted from May 2016 May 2018 in the Ringim community area. The verbal consent of the respondents was sorted. Important of the study were explained to them with aid of the administrative chief, district heads, and community elders. These key elders authenticate and affirm the respondents to be interviewed. Each of the respondents was visited two to three times to verify and have reliable data. In case of any discrepancy obtained between the information given before and those of successive visits on a particular plant, were considered unreliable and rejected. In accordance with conventional inquiry process, data was collected utilizing communicable dialects within the area.

\section{Plants Collection and of Herbarium Specimen Deposition}

Plants species recorded during the interview were collected individually in the field with the aid of respondents confirmed by the elderly people in the community. Plants with variation in their local names were avoided. Collected plants specimen were identified by a certification at Bioresources, National Research Institute for Chemical Technology (NARICT), Zaria, Kaduna State, Nigeria. The identified plant species were subsequently deposited in the herbarium of the research institute. 


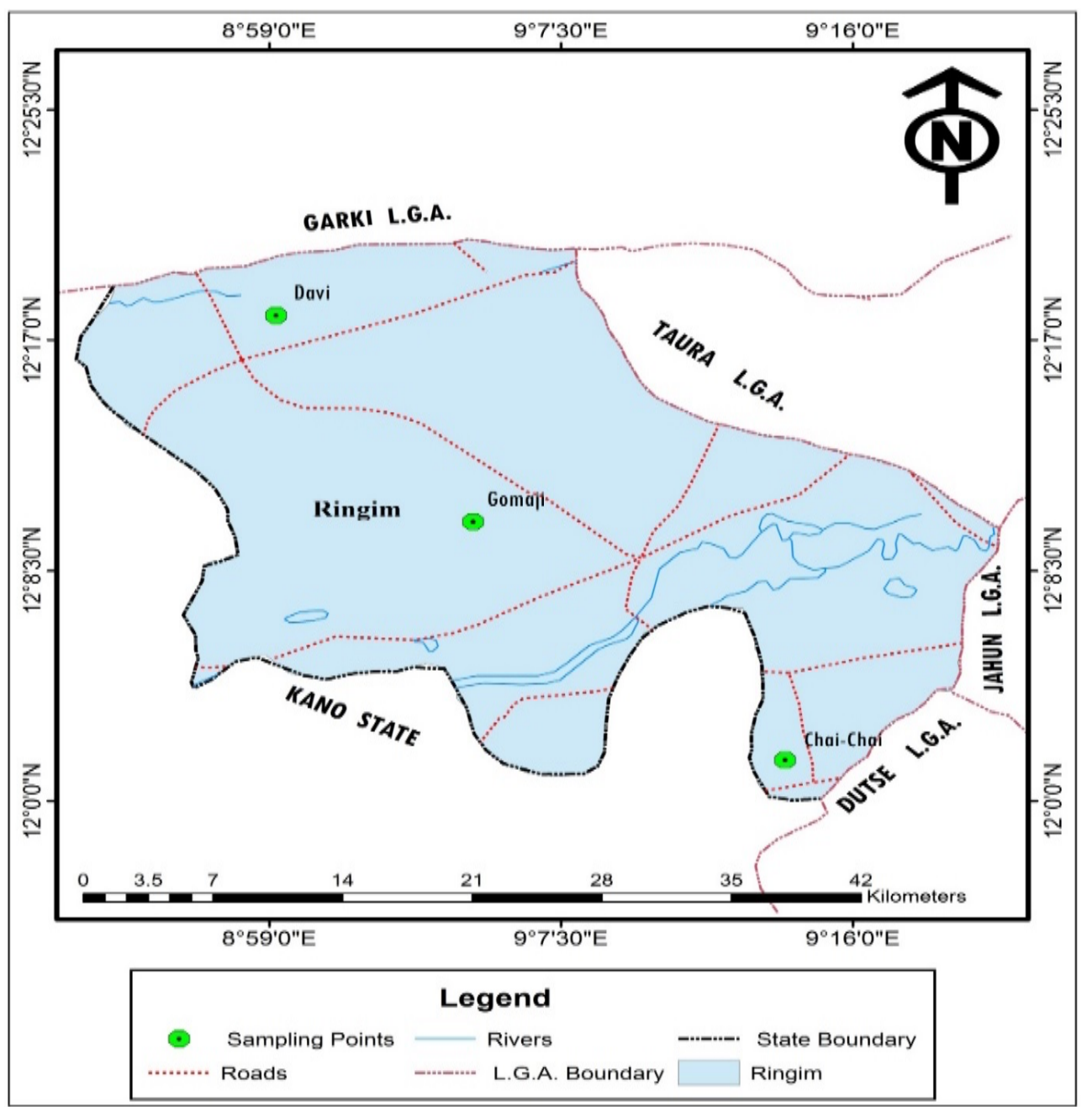

Figure 1. Map of the study area

\section{Data analysis}

The study employed a simple descriptive analysis for the collected ethnobotanical data to determine the frequencies and percentage based on the following information:

i. Socio-demographic information of Respondents (Mahmoud et al. 2020).

ii. Plant taxonomic information, mode of administration, mode of preparation, growth form and parts of plant (Awang et al. 2018).

iii. Quantitative data were computed based on the following indices:

a. To determine the relative importance of a certain plant species, Used Value was used, using the following formula:

$$
U V=\sum U i / N \text {. }
$$

Where $\mathrm{Ui}$ is the total number of uses mentioned, and $\mathrm{N}$ denotes the total number of number of informants interviewed (Abdulrahman et al. 2018).

b. The relative frequency of citation (RFC) was used to assess the popularity of medicinal plant species. The above characteristic was utilized to determine the plant's relative popularity within a community.

$$
\mathrm{RFC}=\mathrm{Fc} / \mathrm{N}
$$

where $\mathrm{Fc}$ is the number of informants who mentioned a certain plant species and $\mathrm{N}$ denotes the total number of informants interviewed (Abdulrahman et al. 2018).

c. Fidelity Level (FL) This measure was used to determine the ability of a plant species to treat a specific ailment. Using the equation below, this parameter was used to determine the ability of a certain plant species to cure inflammatory disease: 


$$
\mathrm{FL}=\mathrm{Ns} / \mathrm{N} \times 100 \text {. }
$$

Where, Ns = the total number of respondents who identified a specific plant species for the treatment of specific diseases and $\mathrm{N}$ is the total number of respondents cited the plants.

\section{Literature Search on Biological Evaluation of mentioned plants by the Respondents}

To discover the in vivo and in vitro research on the mentioned plants by the respondents, a literature search was undertaken using Google Scholar, Scopus, and PubMed for pharmacological properties such as anti-inflammatory, antimicrobial, antioxidant, antibacterial, anticancer, and antiviral.

\section{Results and Discussion}

\section{Sociodemographic information of the respondent $s$}

The ethnobotanical was survey carried out in Ringim. Eighty-one respondents (81) were interviews. The study adopted purposive sampling. Sampling size is not needed. Similar methods were adopted in some ethnobotanical studies carried out by the previous researchers (Abdulrahman et al. 2018). There was no discrimination during the interview. All experienced people certified by the traditional rulers of the community were interviewed. $88.9 \%$ of the respondents interviewed were men and $11.1 \%$ are women respectively (Table 1 ). The dominancy of the men in the research is due to the culture and religion of the study area as said by the respondents. Similar, results were reported in the ethnobotanical studies carried out in Northern Nigeria (Abdulrahman et al. 2018). The majority of the respondents interviewed were found at the age of 30-49 years (55.6\%), followed by 70 and above at $33.3 \%$ (Table 1).

Table 1. Demographic information of the Respondents interviewed

\begin{tabular}{lll}
\hline Parameters & Frequency & Percentage \\
\hline Gender & 72 & 88.9 \\
Male & 9 & 11.1 \\
Female & & \\
Age & 45 & 55.6 \\
$30-49$ & 9 & 11.1 \\
$50-69$ & 27 & 33.3 \\
$70->$ & & \\
Education & 15 & 18.5 \\
Primary education & 9 & 11.1 \\
Secondary education & 4 & 4.9 \\
Tertiary & 43 & 65.4 \\
Religious education & 53 \\
\hline
\end{tabular}

The dominancy of 30-49 years is a result of they are in their active stage they give more time especially, during the field collection. The majority of the respondents did not attend western education but rather they attended religious education from the age of four till date $(65.5 \%)$ (Table 1 ). Only $18.5 \%$ of the respondents attended primary school education while $11.1 \%$ secondary and $4.9 \%$ tertiary education respectively (Table 1$)$. Same situation was reported in ethnobotanical studies of medicinal plants used in the treatment of hepatic ailments in Katsina Northern Nigeria (Kankara et al. 2018). Traditional healers (56.8\%), farmers (30.9\%), elderly people (8.6\%), and traditional birth attendants (3.7\%) were the statuses of the interviewed respondents (Figure 2). The following study is not in agreement with traditional medicinal studies carried out in Northern Nigeria; predominance of women was documented (Kankara et al. 2015). But the predominance was due to the fact that women are more concerned with the maternal healthcare system.
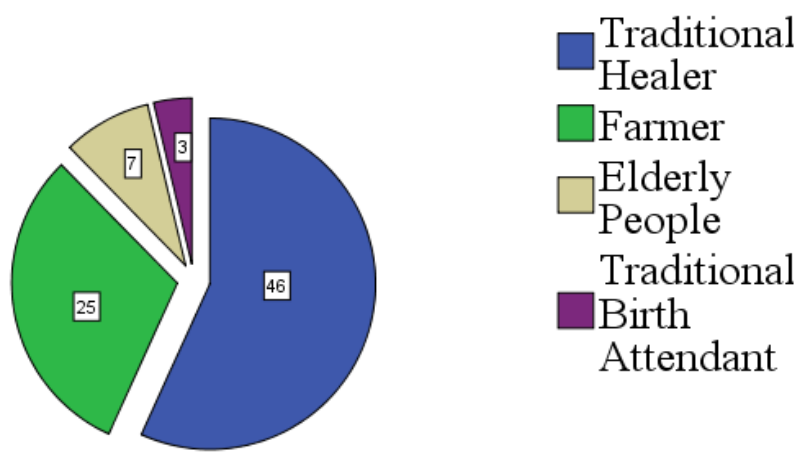

Figure 2. Occupational status of the respondents 
The response of the respondent was computed concerning their community (Figure 3). Chai community was found to give the highest contribution with 34.6\%, Ringim 33.3\%, Gamoji 19.8\%, and Kyarama $12.3 \%$ respectively (Figure 3). This demonstrates that traditional medicinal herbs are being used effectively by all communities to control and improve their health.

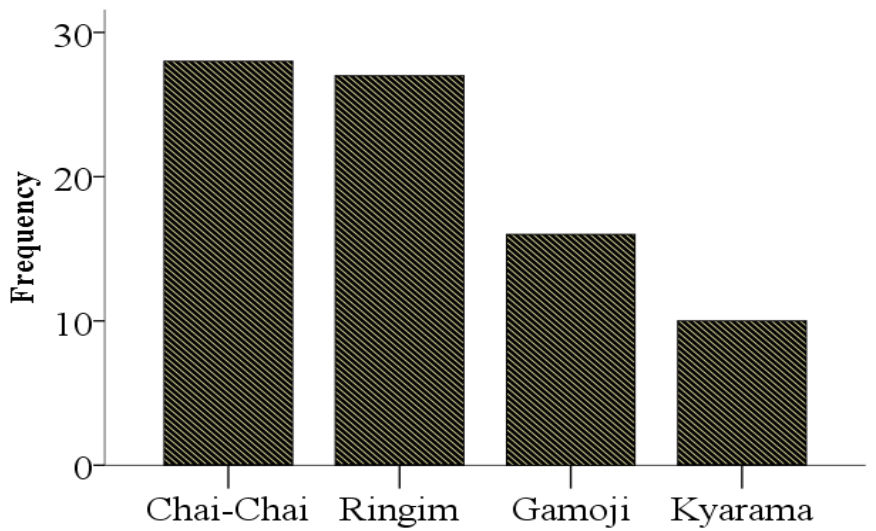

Figure 3. Contributions of zones in respect to medicinal plants documented.

\section{Biodiversity of the documented plants}

The study revealed 47 medicinal plant species, which were divided into 25 families (Figure 4). Species with the same local name were not collected to avoid any misidentification. The domination of the plant families in the flora was found as follows; Leguminosae (10 species), Malvaceae (4 species), Combretaceae (4 species), Anacardiaceae (2 species), Burseraceae (2 species), Euphorbiaceae (2 species), Meliaceae (2 species), Moraceae (2 species), Poaceae (2 species), Poaceae (2 species) and while the remaining families each with one species. There are three types of valuable flora in the region:trees, shrubs, and herbs (Table 2). Despite the loss of traditional culture on natural resources and climate change in the region and around the world, the study found that the region has a great diversity of wild plant species. Leguminosae is one of the most diverse and beneficial plant families. They are grown both in aquatic and in flatland (Abdulrahman et al. 2018). Members of this group range from shrubs, climbers, and trees which were similarly reported in the following study. The diversity of the plants documented in the study, shows how diverse the traditional medicinal practitioners are in the community. Whereby, the studies on medicinal used for the treatment of Malaria in Kafin Hausa reported only 15 species (Zakariya et al. 2021).

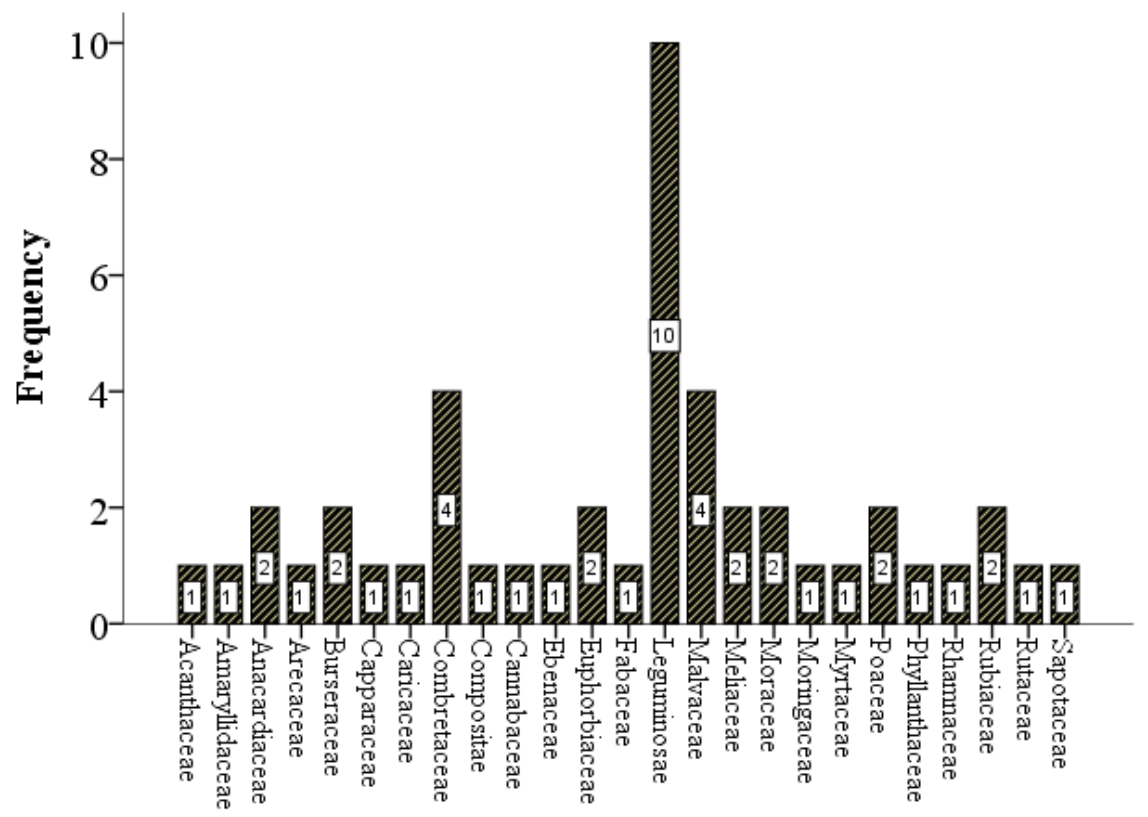

Figure 4. Family distribution of the documented plants in Ringim 


\begin{tabular}{|c|c|c|c|c|c|c|c|c|}
\hline Family name & Scientific name & $\begin{array}{l}\text { Common name } \\
\text { (Hausa) }\end{array}$ & $\begin{array}{l}\text { Major Other } \\
\text { Diseases Treated }\end{array}$ & $\begin{array}{l}\text { Part of the } \\
\text { plant }\end{array}$ & $\begin{array}{l}\text { Method } \\
\text { administration }\end{array}$ & $\begin{array}{l}\text { Method of } \\
\text { preparations }\end{array}$ & $\begin{array}{l}\text { Form and } \\
\text { Domesticatio } \\
\text { n status }\end{array}$ & $\begin{array}{l}\text { Voucher } \\
\text { number }\end{array}$ \\
\hline Acanthaceae & Nelsonia canescens (Lam.) Spreng. & Tsamiyar maharba & Anti-miseals & Stem bark & Bathing & Poultice & Shrub/Wild & 0023 \\
\hline Amaryllidaceae & Allium cepa L. & Albasa & Cold related & Bulb & Oral, Dermal & Infusion & Herb/FUC & 0031 \\
\hline Anacardiaceae & Mangifera indica $\mathrm{L}$. & Mangwaro & Pile & Stem bark & Oral & Poultice & Tree/Wild & 1944 \\
\hline Anacardiaceae & Sclerocarya birrea (A. Rich.) Hochst. & $\begin{array}{l}\text { Lulu danya, } \\
\text { Dawya }\end{array}$ & Diarrhoea & Stem bark & Oral, Dermal & Poultice & Tree/Wild & 0041 \\
\hline Arecaceae & Hyphaene compressa H.Wendl. & Goruba & Dysentry & Fruits & Oral & Poultice & Tree/ Wild & 0067 \\
\hline Burseraceae & Boswellia ameero Balff. & Ararrabi & Stomach upsate & Stem bark & Oral, Dermal & Poultice & Tree/Wild & 0623 \\
\hline Burseraceae & Commiphora africana (A.R ich.) Endl. & Dashi & $\begin{array}{l}\text { Cancer-related } \\
\text { diseases }\end{array}$ & $\begin{array}{l}\text { Steam bark, } \\
\text { leaves }\end{array}$ & Oral & $\begin{array}{l}\text { Decoction/ } \\
\text { Decoction }\end{array}$ & Tree/Wild & 2551 \\
\hline Capparaceae & Maerua angolensis DC. & $\begin{array}{l}\text { Mandiwa, } \\
\text { Chichiwa }\end{array}$ & $\begin{array}{l}\text { Cancer related } \\
\text { disease }\end{array}$ & Stam bark & Oral, Dermal & $\begin{array}{l}\text { Poultice / } \\
\text { Decoction }\end{array}$ & Tree/ Wild & 5532 \\
\hline Caricaceae & Carica papaya L. & Gwanda & Yellow fever & Leaves & Oral, Bathing & Poultice & Tree/FUC & 0078 \\
\hline Combretaceae & Anogeissus leiocarpa (DC.) Guill. Perr. & Marke & $\begin{array}{l}\text { Pile and } \\
\text { Haemorrhoid }\end{array}$ & Stem bark & Oral, Dermal & Poultice & Tree/ Wild & 0061 \\
\hline Combretaceae & Guiera senegalensis J.F. Gmel & Sabara & $\begin{array}{l}\text { Pile and } \\
\text { Haemorrhoid }\end{array}$ & $\begin{array}{l}\text { Stem bark, } \\
\text { Root }\end{array}$ & Oral, Bathing & Poultice & Shrub/Wild & 0071 \\
\hline Combretaceae & Combretum micranthum G. Don & Geza & Ulcer & Leaves & Oral, Bathing & Poultice & Shrub/Wild & 6211 \\
\hline Combretaceae & Combretum lamprocarpum Diels & $\begin{array}{l}\text { Kattakara, } \\
\text { Talauniya }\end{array}$ & $\begin{array}{l}\text { Parasitic stomach } \\
\text { worm }\end{array}$ & Leaves & Oral & Poultice & Shrub/Wild & 7445 \\
\hline Compositae & Centaurea senegalensis DC. & Kayar Rakumi & Burns, wounds & $\begin{array}{l}\text { Whole } \\
\text { plant }\end{array}$ & Bathing & $\begin{array}{l}\text { Poultice / } \\
\text { Decoction }\end{array}$ & Shrub/Wild & 0322 \\
\hline Cannabaceae & Celtis toka (Forssk.) Hepper J.R.I. Wood & Zuwo, Dunki & $\begin{array}{l}\text { Rheumatism/Malar } \\
\text { ial }\end{array}$ & $\begin{array}{l}\text { Leaves, } \\
\text { stem bark }\end{array}$ & Oral & Poultice & Tree/ Wild & 4019 \\
\hline Ebenaceae & Diospyros mespiliformis Hochst. ex A. DC. & Kanya & Tooth ache & Stem bark & Oral & Decoction & Tree/Wild & 0045 \\
\hline Euphorbiaceae & Croton abaitensis Baill. & Gasaya & $\begin{array}{l}\text { Penis function } \\
\text { stimulant }\end{array}$ & Leaves & Oral & Poultice & Shrub/Wild & 0005 \\
\hline Euphorbiaceae & Jatropha aceroides (Pax K. Hoffm.) Hutch. & $\begin{array}{l}\text { Bini da zugu, } \\
\text { Mamulu }\end{array}$ & Constipation & Leaves & Oral & Poultice & Tree/Wild & 0040 \\
\hline Fabaceae & Albizia coriaria Welw. ex Oliver & Katsari & Cancer & Leaves & Oral, Bathing & $\begin{array}{l}\text { Poultice, } \\
\text { infusion }\end{array}$ & Tree/Wild & 0091 \\
\hline Leguminosae & Tamarindus indica $\mathrm{L}$. & Tsamiya & Stomach upsate & Fruits & Oral & Infusion & Tree/Wild & 0087 \\
\hline Leguminosae & Acacia abbreviata Maslin & Duwaduwa & Rheumatic fever & Stembark & Dermal & Decoction & Tree/Wild & 0064 \\
\hline Leguminosae & Acacia hockii De Wild. & Dushe & Skin diseases & Stem bark & Dermal & Decoction & Shrub/Wild & 2416 \\
\hline Leguminosae & Aeschynomene uniflora E.Mey. & Bagaruwar kasa & Body immune & Leaves & Dermal & Poultice & Herb/Wild & 4561 \\
\hline Leguminosae & Senna obtusifolia (L.) H.S.Irwin Barneby & Tafasa & Skin & $\begin{array}{l}\text { Leaves, } \\
\text { whole plant }\end{array}$ & Dermal/Oral & $\begin{array}{l}\text { Poultice / } \\
\text { Decoction }\end{array}$ & Herb/wild & 0233 \\
\hline
\end{tabular}


Ethnobotany Research and Applications

\begin{tabular}{|c|c|c|c|c|c|c|c|c|}
\hline Leguminosae & Detarium beurmannianum Schweinf. & Taura & Rheumatism & Stem bark & Dermal/Oral & $\begin{array}{l}\text { Poultice / } \\
\text { Poultices }\end{array}$ & Tree/Wild & 0076 \\
\hline Leguminosae & Mimosa pigra L. & Kaidaji, Gombi & Diarrhoea/Tonic & Leaves & Oral & Poultice & Shrub/Wild & 2623 \\
\hline Leguminosae & Parkia biglobosa (Jacq.) G. Don & Dorawa & Anti-measles & Stem bark & Dermal/Oral & $\begin{array}{l}\text { Poultice / } \\
\text { Decoction }\end{array}$ & Tree/Wild & 0031 \\
\hline Leguminosae & $\begin{array}{l}\text { Senna acanthoclada (Griseb.) H.S. Irwin } \\
\text { Barneby }\end{array}$ & Majamfari & constipation & $\begin{array}{l}\text { Whole } \\
\text { plant }\end{array}$ & Oral & Poultice & Herb/Wild & 8623 \\
\hline Leguminosae & Senna singueana (Delile) Lock & Runhu & $\begin{array}{l}\text { Immune against } \\
\text { skin diseases }\end{array}$ & Stem bark & Dermal & Poultices & $\begin{array}{l}\text { Shrub/Wild/Vill } \\
\text { age }\end{array}$ & 3773 \\
\hline Malvaceae & Hibiscus sabdariffa L. & Yakuwa/ Zobo & $\begin{array}{l}\text { Hypertension/ } \\
\text { Diabetes }\end{array}$ & Flower & Oral & Poultice & Shrub/ FUC & 0032 \\
\hline Meliaceae & Azadirachta indica A. Juss. & Maina, Darbejiya & Anti-malaria & Leaves & Oral & Poultice & Tree/ FUC & 0020 \\
\hline Meliaceae & Khaya senegalensis (Desv.) A.J uss. & Madaci & Stomach pain & Stem bark & Oral & Poultice & Tree/ Wild & 4167 \\
\hline Moraceae & Ficus sycomorus $\mathrm{L}$. & Baure & Anti-epileptic & Stem bark & Oral & Poultice & Tree/ Wild & 0110 \\
\hline Moraceae & Ficus thonningii Blume & Chediya, Shirinya & Dysentery & Stem bark & Oral & Poultice & Tree/Wild & 2121 \\
\hline Moringaceae & Moringa oleifera Lam. & Zogale & $\begin{array}{l}\text { Hypertension/ } \\
\text { Diabetes }\end{array}$ & $\begin{array}{l}\text { Leaves, } \\
\text { Whole } \\
\text { plant }\end{array}$ & Oral & Poultice & Tree/FUC/Wild & 0993 \\
\hline Myrtaceae & Psidium guajava L. & Gwaiba & $\begin{array}{l}\text { Hypertension/ } \\
\text { Diabetes/ Malaria }\end{array}$ & $\begin{array}{l}\text { Leaves/ } \\
\text { Whole } \\
\text { plant }\end{array}$ & Oral/ Dermal & $\begin{array}{l}\text { Poultice / } \\
\text { Decoction }\end{array}$ & $\begin{array}{l}\text { Shrub/FUC/Wil } \\
\text { d }\end{array}$ & 2311 \\
\hline Malvaceae & Adansonia digitata $\mathrm{L}$. & Kuka & Body immune & Leaves & Oral & Poultice & Tree/Wild & 0075 \\
\hline Malvaceae & Ceiba acuminata (S. Watson) Rose & Rimi & Stomach pain & Stem bark & Oral & Poultice & Tree/ Wild & 1517 \\
\hline Malvaceae & Sterculia setigera Delile & Kukuki & $\begin{array}{l}\text { Respiratory/ snake } \\
\text { bites }\end{array}$ & $\begin{array}{l}\text { Leaves/ste } \\
\mathrm{m} \text { bark }\end{array}$ & Oral/Dermal & $\begin{array}{l}\text { Poultice / } \\
\text { Decoction }\end{array}$ & Tree/ Wild & 0017 \\
\hline Poaceae & Urelytrum giganteum Pilg. & Jema & Stomach disorder & Leaves & Oral & Poultice & Herb/Wild & 0722 \\
\hline Poaceae & Pennisetum advena Wipff Veldkamp & Hura & Anti-diarrhea & Leaves & Oral & Poultice & Herb/Wild & 1897 \\
\hline Phyllanthaceae & Phyllanthus abditus G.L. Webster & Zogalen kuda & Ringworm & Leaves & Oral & Poultice & Tree/Wild & 2901 \\
\hline Rhamnaceae & Ziziphus spina-christi (L.) Desf. & Magarya & $\begin{array}{l}\text { Stomach pain/ } \\
\text { Chest }\end{array}$ & Leaves & Oral/ Dermal & $\begin{array}{l}\text { Poultice / } \\
\text { Decoction }\end{array}$ & Tree/Wild & 9342 \\
\hline Rubiaceae & Mitragyna diversifolia (Wall. ex G. Don) Havil. & Giyayya & Skin infection & Leaves & Dermal & Decoction & Herb/Wild & 4115 \\
\hline Rutaceae & Citrus aurantiaca Swingle & Lemon tsami & Malaria fever & Leaves & Bathing & Infusion & Tree/FUC & 1101 \\
\hline Rubiaceae & Spermacoce suaveolens (G. Mey.) Kuntze & Alkamar tururuwa & Eczema & $\begin{array}{l}\text { Whole } \\
\text { plant }\end{array}$ & Dermal & Decoction & Herb/Wild & 1153 \\
\hline Sapotaceae & Vitellaria paradoxa C.F. Gaertn. & Kadanya & Skin infection & Leaves & Oral/Dermal & $\begin{array}{l}\text { Poultice / } \\
\text { Decoction }\end{array}$ & Tree/ Wild & 0060 \\
\hline
\end{tabular}

Note:S/N = Serial Number, FUC = Field Under Cultivation. 


\section{Determination of the popularity and effectiveness of the documented plant species}

Quantitative ethnobotany improves the chances of identifying promising pharmacologically significant plants in the community (Awan et al. 2021). Used Value, relative frequency citations, fidelity level and information consensus factors were reported as good index for determination of usefulness and effectiveness of plant species in a particular community (Kankara et al. 2015). Quantitatively all the 47 reported medicinal plants were found to be popular (Table 3). In Ringim, plants with an RFC value of 0.9 are the most popular, while those with an FL value of $80 \%$ are the most effective in the treatment and management of inflammation (Table 3).

Table 3. Popularity and effectiveness of Documented plant Species based on the RFC and FL.

\begin{tabular}{|c|c|c|c|}
\hline Species name & UV & RFC & FL\% \\
\hline Nelsonia canescens (Lam.) Spreng. & 0.06 & 0.6 & 80 \\
\hline Allium cepa L. & 0.04 & 0.7 & 91 \\
\hline Mangifera indica $L$. & 0.06 & 0.6 & 98 \\
\hline Sclerocarya birrea (A.Rich.) Hochst. & 0.07 & 0.9 & 87 \\
\hline Hyphaene compressa H. Wendl. & 0.02 & 0.8 & 80 \\
\hline Boswellia ameero Balf.f. & 0.02 & 0.6 & 87 \\
\hline Commiphora africana (A. Rich.) Endl. & 0.07 & 0.9 & 77 \\
\hline Maerua angolensis DC. & 0.04 & 0.7 & 66 \\
\hline Carica papaya L. & 0.02 & 0.9 & 77 \\
\hline Anogeissus leiocarpa (DC.) Guill. Perr. & 0.07 & 0.8 & 90 \\
\hline Guiera senegalensis J.F. Gmel & 0.02 & 0.6 & 87 \\
\hline Combretum micranthum G.Don & 0.04 & 0.9 & 87 \\
\hline Combretum lamprocarpum Diels & 0.02 & 0.6 & 80 \\
\hline Centaurea senegalensis DC. & 0.07 & 0.7 & 90 \\
\hline Celtis toka (Forssk.) Hepper J.R.I. Wood & 0.02 & 0.7 & 87 \\
\hline Diospyros mespiliformis Hochst. ex A. DC. & 0.07 & 0.8 & 77 \\
\hline Croton abaitensis Baill. & 0.02 & 0.9 & 87 \\
\hline Jatropha aceroides (Pax K. Hoffm.) Hutch. & 0.06 & 0.6 & 80 \\
\hline Albizia coriaria Welw. ex Oliver & 0.02 & 0.7 & 91 \\
\hline Tamarindus indica L. & 0.07 & 0.6 & 80 \\
\hline Acacia abbreviata Maslin & 0.02 & 0.7 & 91 \\
\hline Acacia hockii De Wild. & 0.07 & 0.6 & 98 \\
\hline Aeschynomene uniflora E. Mey. & 0.04 & 0.9 & 87 \\
\hline Senna obtusifolia (L.) H.S. Irwin Barneby & 0.07 & 0.6 & 80 \\
\hline Detarium beurmannianum Schweinf. & 0.06 & 0.8 & 87 \\
\hline Mimosa pigra L. & 0.07 & 0.8 & 77 \\
\hline Parkia biglobosa (Jacq.) G. Don & 0.07 & 0.9 & 87 \\
\hline Senna acanthoclada (Griseb.) H.S. Irwin Barneby & 0.04 & 0.6 & 77 \\
\hline Senna singueana (Delile) Lock & 0.06 & 0.6 & 90 \\
\hline Hibiscus sabdariffa L. & 0.02 & 0.9 & 87 \\
\hline Azadirachta indica A. Juss. & 0.07 & 0.8 & 87 \\
\hline Khaya senegalensis (Desv.) A. Juss. & 0.06 & 0.6 & 80 \\
\hline Ficus sycomorus $\mathrm{L}$. & 0.07 & 0.9 & 90 \\
\hline Ficus thonningii Blume & 0.02 & 0.7 & 66 \\
\hline Moringa oleifera Lam. & 0.07 & 0.9 & 87 \\
\hline Psidium guajava $\mathrm{L}$. & 0.04 & 0.6 & 66 \\
\hline Adansonia digitata $\mathrm{L}$ & 0.06 & 0.6 & 90 \\
\hline Ceiba acuminata (S. Watson) Rose & 0.02 & 0.7 & 90 \\
\hline Sterculia setigera Delile & 0.04 & 0.8 & 87 \\
\hline Urelytrum giganteum Pilg. & 0.06 & 0.6 & 80 \\
\hline Pennisetum advena Wipff Veldkamp & 0.06 & 0.9 & 91 \\
\hline Phyllanthus abditus G.L.Webster & 0.06 & 0.8 & 98 \\
\hline Ziziphus spina-christi (L.) Desf. & 0.04 & 0.6 & 87 \\
\hline Mitragyna diversifolia (Wall. ex G. Don) Havil. & 0.02 & 0.9 & 80 \\
\hline Citrus aurantiaca Swingle & 0.02 & 0.7 & 87 \\
\hline Spermacoce suaveolens (G.Mey.) Kuntze & 0.02 & 0.9 & 77 \\
\hline Vitellaria paradoxa C.F.Gaertn. & 0.07 & 0.6 & 87 \\
\hline
\end{tabular}

Part of the plant, method of preparation and administration for the treatment of inflammation

Leaves were reported the most utilised part (42.6\%), followed by Stem bark (37\%), whole plants (11.1\%), fruits (3.7), then bulb, flower, and root (1.9\%) respectively (Figure 5). The respondents as shown preference in the usage of the leaves and bark stem for the treatment of inflammation and its related cases. The respondents attributed their preference of the following plant parts due to their effectiveness, easier collection, and avoiding the extinction of the species by the collection of the plant root. Previously it was reported that leaves and barks stems are the ideal areas for secondary metabolite manufacturing and storage, which are responsible for the plant's biological characteristics (Abdulrahman et al. 2018). Similarly, ethnobotanical studies of traditional medicinal plants used by birth attendants in Côte d'Ivoire justified the leaves and bark stem preference due to the ease with which the collection of parts and easily regenerated (Koman et al., 2021). Only three methods of preparation of medicinal plants were reported in the following studies; decoction (28.1), infusion (7\%), and poultice (64.9) (Figure 6). The following methods were used due to the nature of the disease reported by the respondents. The decoction was known as the fastest means of extracting the component of the plant parts (Koman et al., 2021). Respondents claimed dermal medication is higher than the oral method. As they believed most of the causes are external. The study is in agreement with the study of Arunachal Pradesh, India on traditional medicinal plants used for anti-inflammatory (Namsa et al., 2009). 


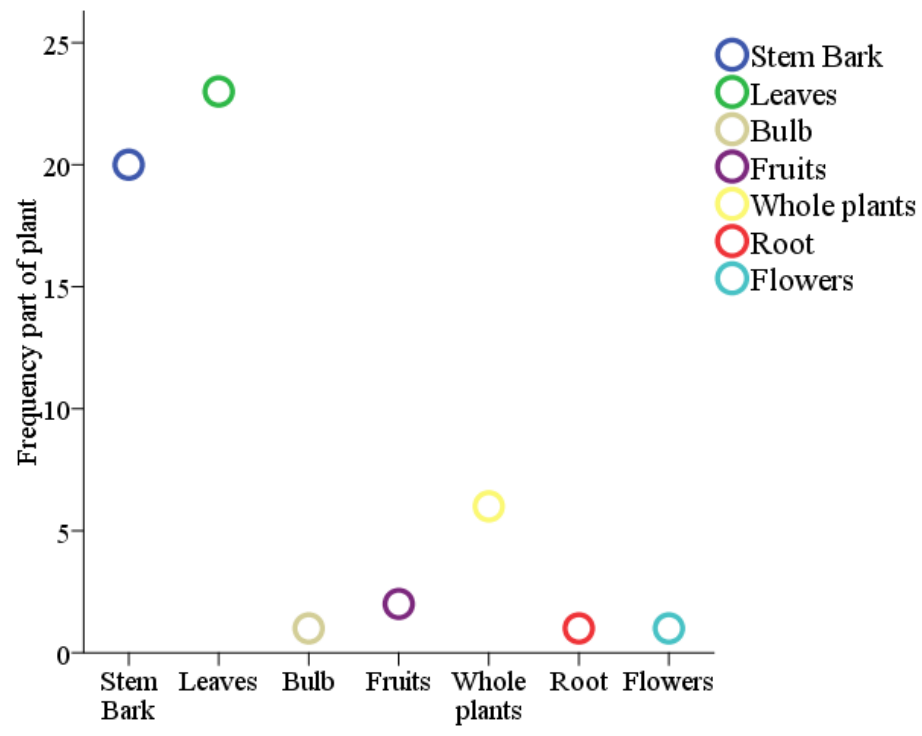

Figure 5. Parts of the plants used for the management of Inflammation in Ringim

Diagnosis and dosage regimen of inflammation

It depends on the traditional herbalist on the diagnosis of the causes of the inflammation. The majority of the respondents (83\%) asked the patients if they are feverish, check their tongues, asked whether the inflammation was a result of minor or serious accidents to ascertain the cause of the inflammation. Only $(17 \%)$ of the respondents give medication by mere observation. Generally, the medication is applied thrice a day in the affected area daily until fully recovered. It depends on the magnitude of the infection,

if it is serious, bathing, oral and dermal medication is prescribed. For the preparation of the medication, water, holy water (Zamzam), honey, black seed oil, garlic oil are used as diluents for the preparation of the medication. None of the respondents reported the negative side effect of the prescribed medication. Some studies reported water as the means of diluent of traditional medicinal plants (Namsa et al., 2009).

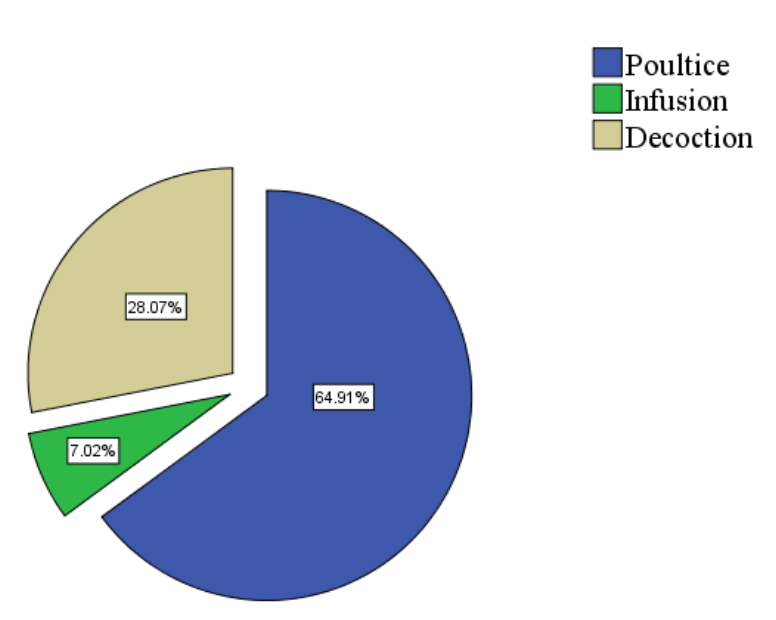

Figure 6. Methods of Preparation of the plant parts used for the management of Inflammation in Ringim

\section{Literature review on biological evaluation of mentioned plants by the respondents}

According to the literature, the majority of the plants mentioned by respondents in this survey have been evaluated in vitro or in vivo, and some cases both. This adds to the study's conclusions' believability. This has been shown (Table 4). Based on these findings, more research is needed to determine the safety, standardization, and dosing regimen for these extracts and compounds from medicinal plants. Extensive pre-clinical and clinical trials aimed at developing new and/potent anti-inflammatory drugs should also be conducted on these plants, as their reported use in traditional medicine and high/potent activities demonstrated scientifically make them a promising source of new anti-inflammatory drugs candidates. No scientific reports with regards to $H$. compressa, $C$. lamprocarpum, C. toka, C. abaitensis, J. aceroides, A. coriaria, S. acanthoclada, C. acuminata, U. giganteum, $P$. advena, $P$. abditus, $C$. aurantiaca and $S$. suaveolens. Because the respondents claim that the aforementioned plants are effective in the treatment of inflammatory and related illnesses, pharmacological study on them is required.

\section{Conclusion}

The utilisation of medicinal plants by the traditional herbalist of Ringim for treatment and management of inflammation is properly documented. The present study revealed the people of Ringim, Jigawa state, Northern part of Nigeria rely on traditional medicine to treat various ailments. The study also revealed both the young and aged people of the community are the custodian of traditional knowledge to treat ailments. Men are the most knowledgeable of traditional medicinal plants in the community. The study will serve as an avenue for the exploration of this untapped knowledge for herbal product formulations, new modern drugs, and monographs of medicinal plants in Northern Nigeria and Nigeria at large. 
Table 4. Literature review on Biological Evaluation of mentioned plants by the Respondents

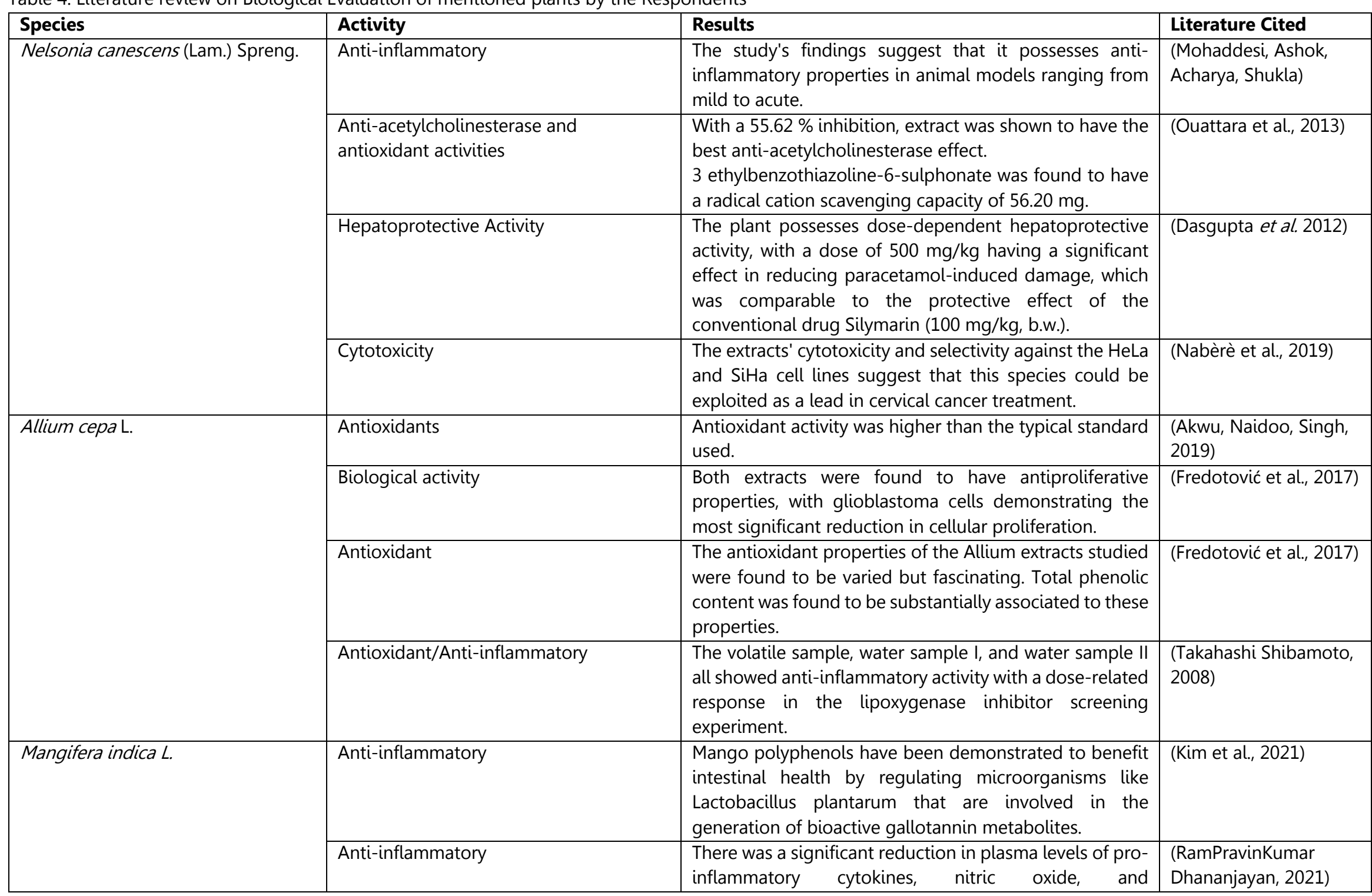




\begin{tabular}{|c|c|c|c|}
\hline & & $\begin{array}{l}\text { malondialdehyde; and the expression levels of mRNA of } \\
\text { induced nitric oxide synthase and intercellular adhesion } \\
\text { molecule of animals treated with } 0.2 \text { and } 0.4 \mathrm{~g} / \mathrm{kg} \text { of EEMI } \\
\text { in comparison to disease control. }\end{array}$ & \\
\hline & Anti-inflammatory & $\begin{array}{l}\text { Inhibition of IL-4 and IL-5 cytokines, as well as IgE levels } \\
\text { and cell proliferation, in bronchoalveolar lavage fluid and } \\
\text { lymphocyte culture supernatant resulted in a } \\
\text { considerable reduction in airway inflammation } \\
\text { surrounding arteries and bronchi. }\end{array}$ & (Rivera et al., 2011) \\
\hline \multirow[t]{3}{*}{ Sclerocarya birrea (A. Rich.) Hochst. } & Anti-inflammatory & $\begin{array}{l}\text { In a time-dependent manner (SB, } 500 \mathrm{mg} / \mathrm{kg} \text { p.o.) } \\
\text { reduced rat paw oedema caused by subplantar injections } \\
\text { of fresh egg albumin. }\end{array}$ & (J. A. Ojewole, 2003) \\
\hline & Antimicrobial & $\begin{array}{l}\text { When compared to the negative control of } 1 \% \text { DMSO, } \\
\text { the extract preventing the synthesis of violacein, with a } \\
\text { suppression of } 70.19 \text { percent. The inhibitory impact of } \\
\text { ascorbic acid, which was used as a control, is much } \\
\text { stronger. }\end{array}$ & (Paré et al. 2021) \\
\hline & In vitro & $\begin{array}{l}\text { exhibited decreased cytotoxicity in normal human } \\
\text { dermal fibroblasts, implying that it could be used as a } \\
\text { cancer-selective agent. }\end{array}$ & (Russo et al., 2018) \\
\hline Hyphaene compressa $\mathrm{H}$. Wendl. & Nill & Nill & Nill \\
\hline \multirow[t]{2}{*}{ Boswellia ameero Balf.f. } & Antioxidant & $\begin{array}{l}\text { At } 200 \mathrm{~g} / \mathrm{mL} \text {, the antioxidant activity of the essential oil } \\
\text { was determined to be } \mid C_{50}=175.2 \mathrm{~g} / \mathrm{mL} \text {. }\end{array}$ & (N. A. A. Ali et al., 2008) \\
\hline & Antimicrobial & $\begin{array}{l}\text { Antibacterial activity was discovered in Gram-positive } \\
\text { bacteria, particularly multi resistant Staphylococcus } \\
\text { strains. The most activity was seen in the methanolic } \\
\text { extract. }\end{array}$ & $\begin{array}{l}\text { (Mothana Lindequist, } \\
\text { 2005) }\end{array}$ \\
\hline \multirow[t]{3}{*}{ Commiphora africana (A. Rich.) Endl. } & Antioxidative, anti-inflammatory & $\begin{array}{l}\text { In vitro, it showed significant antioxidant and anti- } \\
\text { inflammatory activities. Polar extracts reduced iron levels } \\
\text { by acting as radical scavengers (III). Prostaglandin } \\
\text { production was significantly decreased }\end{array}$ & (Compaoré et al. 2016) \\
\hline & Anti-inflammatory and Pain in Rodents & $\begin{array}{l}\text { The hydro-ethanolic } \text { (stem-bark) extract has a } \\
\text { substantial anti-inflammatory effect }(<0.05) \text { and prevents } \\
\text { acetic acid-induced abdominal constriction in mice. }\end{array}$ & (Ezekiel et al. 2010) \\
\hline & hypoglycaemic & $\begin{array}{l}\text { Three doses of the extract were given }(100,200, \text { and } 400 \\
\mathrm{mg} / \mathrm{kg}) \text {. Blood glucose levels were significantly reduced }\end{array}$ & (Goji et al. 2009) \\
\hline
\end{tabular}




\begin{tabular}{|c|c|c|c|}
\hline & & $\begin{array}{l}\text { after one day of medication with a dose of } 400 \mathrm{mg} / \mathrm{kg} \text {. } \\
\text { Blood glucose levels were significantly lower after } 5 \text { and } \\
7 \text { days of therapy with dosages of } 200 \text { and } 400 \mathrm{mg} / \mathrm{kg} \\
\text { when compared to control. }\end{array}$ & \\
\hline \multirow[t]{2}{*}{ Maerua angolensis DC. } & Antioxidant activity & $\begin{array}{l}\text { Butanoic fractions had the best anti-FRAP }(535.961 \mu \mathrm{mol} \\
\text { AAEAC/g of fraction), anti-ABTS }(155.868 \mu \mathrm{mol} \text { TEAC/g } \\
\text { of fraction), and anti-DPPH ( } 81.109 \mathrm{~mol} \text { QEAC/g of } \\
\text { fraction) activity. }\end{array}$ & (Meda et al. 2013) \\
\hline & Analgesic Property & $\begin{array}{l}\text { The extract dose of } 3 \text { and } 10 \mathrm{mg} / \mathrm{kg} \text { had no effect on the } \\
\text { animals' motor coordination in the rotarod test, showing } \\
\text { that no central depressive effect was present. }\end{array}$ & (Iliya Woode, 2014) \\
\hline \multirow[t]{3}{*}{ Carica papaya $\mathrm{L}$. } & Thrombocytosis and Anti-inflammatory & $\begin{array}{l}\text { In thrombocytopenic rats, a high dose of mature leaf } \\
\text { concentrate substantially significant at } \mathrm{P}<0.05 \text {. }\end{array}$ & (Gammulle et al., 2012) \\
\hline & $\begin{array}{l}\text { Anti-inflammatory and } \\
\text { immunomodulatory }\end{array}$ & $\begin{array}{l}\text { The extracts significant at } p<0.05 \text { reduced paw oedema } \\
\text { in the carrageenan test. Similarly, the extract lowered the } \\
\text { amount of granuloma produced, decreasing it from } 0.58 \\
\text { to } 0.22\end{array}$ & (Owoyele et al. 2008) \\
\hline & Antioxidant and Anti-Inflammatory & $\begin{array}{l}\text { Both hydrogen peroxide and superoxide anion have } \\
\text { been discovered to be efficient antioxidants. The effect } \\
\text { of plant extracts on T cells and imDC was confirmed by a } \\
\text { dose-dependent decrease in TNF- production. }\end{array}$ & (Sagnia et al., 2014) \\
\hline \multirow[t]{3}{*}{$\begin{array}{l}\text { Anogeissus leiocarpa (DC.) Guill. } \\
\text { Perr. }\end{array}$} & Anti-nociceptive and anti-pyretic & $\begin{array}{l}\text { At } \mathrm{p}<0.05 \text {, doses of } 200 \text { and } 400 \mathrm{mg} / \mathrm{kg} \text { reduced } \\
\text { produced pain and pyrexia in a way that was equivalent } \\
\text { to the positive controls. }\end{array}$ & (Adejoh et al. 2019) \\
\hline & Wound healing & $\begin{array}{l}\text { The wound area shrank with time, indicating that the } \\
\text { formulations were successful in treating the wounds. By } \\
\text { the } 15 \text { th day, the mixture of } 100 \mathrm{mg} / \mathrm{mL} \text { aqueous extract } \\
\text { and } 10 \% \mathrm{w} / \mathrm{w} \text { powdered ointment of } A \text {. leiocarpus had } \\
\text { healed completely, identical to the typical antibiotic ( } 2 \% \\
\text { w/w penicillin). }\end{array}$ & (Barku et al. 2013) \\
\hline & Antioxidant and Cytotoxic & $\begin{array}{l}\text { When compared to the standard, the results showed } \\
\text { significant antioxidant activity. None of the bioactive } \\
\text { fractions were found to be cytotoxic in the cytotoxicity } \\
\text { tests. }\end{array}$ & (Eltayeb Ali, 2016) \\
\hline Guiera senegalensis J.F. Gmel & Gastroprotective & $\begin{array}{l}\text { In all tests employed, the leaf extract }(50,100 \text {, and } 200 \\
\mathrm{mg} / \mathrm{kg} \text { significantly reduced the ulcer at } \mathrm{P}<0.05 \text {. }\end{array}$ & (Akuodor et al., 2013) \\
\hline
\end{tabular}




\begin{tabular}{|c|c|c|c|}
\hline & Anti-hepatitis B & $\begin{array}{l}\text { Isolated compounds such as quercetin and myricetin-3- } \\
\text { O-rhamnoside. HBsAg and HBeAg production were both } \\
\text { suppressed to about } 60 \% \text { and } 62 \text { percent, respectively. }\end{array}$ & (Parvez et al. 2020) \\
\hline & $\begin{array}{l}\text { Antiplasmodial, analgesic and anti- } \\
\text { inflammatory }\end{array}$ & $\begin{array}{l}\text { Extracts were found to be safe at } 600 \mathrm{mg} / \mathrm{kg} \text { body weight } \\
\text { in mice, with an LD50 of } 1100 \mathrm{mg} / \mathrm{kg} \mathrm{bw} \text {. Only the } \\
\text { methanolic fraction had an antiplasmodial effect, but the } \\
\text { ethyl acetate and hexane fractions were ineffective. }\end{array}$ & (Jigam et al. 2011) \\
\hline \multirow[t]{3}{*}{ Combretum micranthum G. Don } & Anti-inflammatory & $\begin{array}{l}\text { The extract }(50,100 \mathrm{mg} / \mathrm{kg}) \text { significantly reduced the } \\
\text { development of carrageenan-induced oedema in rats at } \\
\mathrm{P}<0.05 \text {. }\end{array}$ & (Olajide et al. 2003) \\
\hline & Nephroprotective activity & $\begin{array}{l}\text { Reduced CP-induced kidney damage markers, oxidative } \\
\text { stress, and histological abnormalities at all doses, } \\
\text { resulting in restored renal function. }\end{array}$ & (Kpemissi et al., 2019) \\
\hline & Anti-hyperglycaemic & $\begin{array}{l}\text { Of the doses studied, the extract dose of } 100 \mathrm{mg} / \mathrm{kg} \text { was } \\
\text { the most effective. It has a hypoglycaemic and anti- } \\
\text { diabetic effect similar to that of a standard drug at } 0.6 \\
\mathrm{mg} / \mathrm{kg} \text { glibenclemide. }\end{array}$ & (Chika Bello, 2010) \\
\hline Combretum lamprocarpum Diels & Nill & Nill & Nill \\
\hline $\begin{array}{l}\text { Celtis toka (Forssk.) Hepper J.R.I. } \\
\text { Wood }\end{array}$ & Nill & Nill & Nill \\
\hline \multirow[t]{3}{*}{$\begin{array}{l}\text { Diospyros mespiliformis Hochst. ex } \\
\text { A. DC. }\end{array}$} & Antimalarial & $\begin{array}{l}\text { It have antimalarial properties against resistant } \\
\text { Plasmodium berghei infection in mice, as well as } \\
\text { increased cell viability and mito-protection, and they are } \\
\text { not toxic. }\end{array}$ & (Olanlokun et al. 2021) \\
\hline & Antimalarial & $\begin{array}{l}\text { In the curative and suppressive tests, the extract (50-200 } \\
\mathrm{mg} / \mathrm{kg} \text { has a strong dose-dependent impact against the } \\
\text { parasite, as well as a repository effect at high dosages at } \\
100 \text { and } 200 \mathrm{mg} / \mathrm{kg}\end{array}$ & (Adzu Salawu, 2009) \\
\hline & Inflammatory effects & $\begin{array}{l}\text { According to this study, the extracts exerts } \\
\text { immunomodulatory effects in infected mice, limiting } \\
\text { malaria parasite replication and so protecting liver cells. }\end{array}$ & (David et al., 2021) \\
\hline Croton abaitensis Baill. & Nill & Nill & Nill \\
\hline
\end{tabular}




\begin{tabular}{|c|c|c|c|}
\hline $\begin{array}{l}\text { Jatropha aceroides (Pax K. Hoffm.) } \\
\text { Hutch. }\end{array}$ & Nill & Nill & Nill \\
\hline Albizia coriaria Welw. ex Oliver & Nill & Nill & Nill \\
\hline \multirow[t]{3}{*}{ Tamarindus indica L. } & Anti-inflammatory & $\begin{array}{l}\text { The findings showed that the extract significantly } \\
\text { reduced carrageenan-induced paw edema in rats at } P< \\
0.01 \text {. }\end{array}$ & (Suralkar et al. 2012) \\
\hline & Anti-inflammatory & $\begin{array}{l}\text { In an acute inflammation model, the aqueous extract to } \\
\text { have good anti-inflammatory action. }\end{array}$ & $\begin{array}{l}\text { (Udupa, Rathnakar, } \\
\text { Udupa, 2007) }\end{array}$ \\
\hline & Anti-inflammatory and anti-oxidant & $\begin{array}{l}\text { With lower } \mathrm{IC}_{50} \text { values, the stem bark extract was a } \\
\text { stronger scavenger of both DPPH radicals and hydrogen } \\
\text { peroxide than the root extract. Both extracts } \\
\text { demonstrated dose-dependent reductions in edema in } \\
\text { the anti-inflammation test, similar to the conventional } \\
\text { medicines utilized. }\end{array}$ & (Borquaye et al. 2020) \\
\hline Acacia abbreviata Maslin & Antioxidant and hepatoprotective & $\begin{array}{l}\text { With an EC50 of } 6.3 \mathrm{~g} / \mathrm{mL} \text { in DPPH and } 19.15 \mathrm{mM} \text { FeSO4 } \\
\text { equivalent/mg sample in the FRAP experiment, the } \\
\text { extract showed strong antioxidant activity. The extract } \\
\text { significantly reduced the activities of ALT, AST, and GGT } \\
\text { by } 11 \text { percent, } 35.7 \text { percent, and } 65 \text { percent, respectively. }\end{array}$ & (Sobeh et al., 2018) \\
\hline \multirow[t]{3}{*}{ Acacia hockii De Wild. } & Anti-inflammatory & $\begin{array}{l}\text { Normal diclofenac reduced inflammation by } 1.11 \% \text { to } 4.9 \\
\% \text {, whereas stem bark extract reduced inflammation by } \\
0.6 \text { percent to } 5.38 \% \text {. }\end{array}$ & (Kamau et al. 2016) \\
\hline & Antipyretic & $\begin{array}{l}\text { The stem bark extract lowered rectal temperature in } \\
\text { pyretic rats by } 0.62-3.8 \% \text {, while aspirin reduced rectal } \\
\text { temperature by } 0.63-3.1 \% \text {. }\end{array}$ & $\begin{array}{l}\text { (Kamau, Nthiga, Safari, } \\
\text { et al., 2016) }\end{array}$ \\
\hline & Antimicrobial and Antioxidant & $\begin{array}{l}\text { The extracts' minimum inhibitory doses ranged from } \\
0.625 \mathrm{mg} / \mathrm{mL} \text { to } 5 \mathrm{mg} / \mathrm{mL} \text {. With an inhibitory proportion } \\
\text { of up to } 95.88 \% \text {, both extracts substantially inhibited } \\
\text { sporulation. The antioxidant activity of the extracts } \\
\text { ranged from } 6 \text { to } 96 \% \text {. The extracts contain antibacterial } \\
\text { and antioxidant properties. }\end{array}$ & (Lagnika et al. 2016) \\
\hline Aeschynomene uniflora E. Mey. & Anti-inflammatory & $\begin{array}{l}\text { Toxicity tests revealed that no one died in any of the } \\
\text { groups, even when the dose was increased to } 5000 \\
\mathrm{mg} / \mathrm{kg} \text {. The dose of } 1000 \mathrm{mg} / \mathrm{kg} \text { showed more activity } \\
\text { than the Control, followed by } 250 \mathrm{mg} / \mathrm{kg} \text {, and ultimately } \\
500 \mathrm{mg} / \mathrm{kg} \text {, indicating efficacy. }\end{array}$ & $\begin{array}{l}\text { (Anas, Ambi, Zainab, } \\
\text { Jajere, Umar, 2018) }\end{array}$ \\
\hline
\end{tabular}




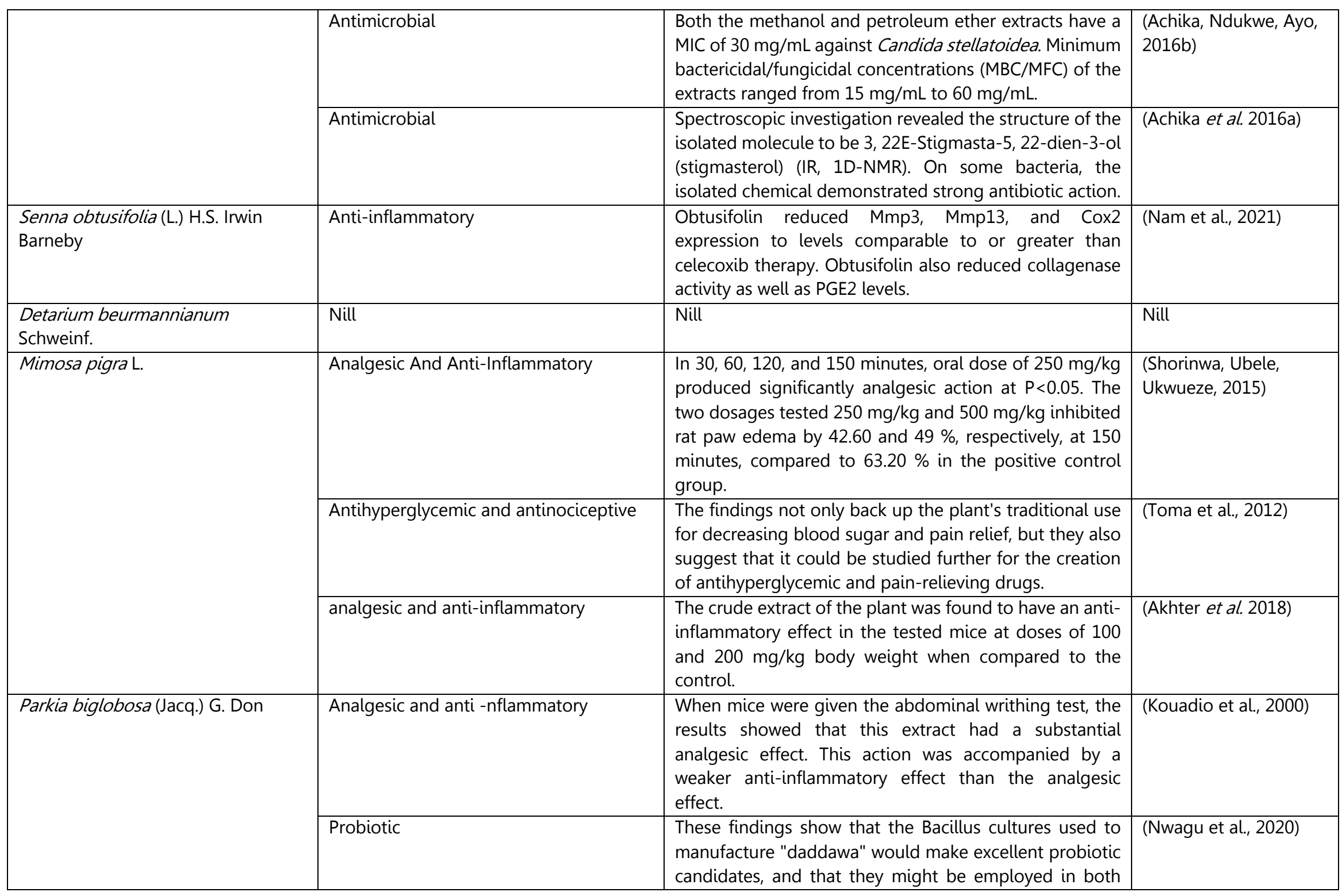




\begin{tabular}{|c|c|c|c|}
\hline & & $\begin{array}{l}\text { animal and human formulations to promote consumer } \\
\text { health. }\end{array}$ & \\
\hline & Cardioprotective & $\begin{array}{l}\text { ISO produced MI in infarcted rats, which was marked by } \\
\text { a substantial rise in MDA }(\mathrm{P}<0.001) \text {, biochemical } \\
\text { abnormalities, cardiac hypertrophy, and histological } \\
\text { alterations. HAE significantly }(\mathrm{P}<0.001) \text { reduced the } \\
\text { induction of all of these defects in pre-treated rats. May } \\
\text { have cardioprotective qualities against ISO-induced MI, } \\
\text { according to these data. }\end{array}$ & (Adi et al., 2013) \\
\hline $\begin{array}{l}\text { Senna acanthoclada (Griseb.) H.S. } \\
\text { Irwin Barneby }\end{array}$ & Nill & Nill & Nill \\
\hline \multirow[t]{3}{*}{ Senna singueana (Delile) Lock } & $\begin{array}{l}\text { Antioxidant, Hepatoprotective, } \\
\text { Antiapoptotic }\end{array}$ & $\begin{array}{l}\text { It significantly reduced elevated AST (aspartate } \\
\text { aminotransferase) and total bilirubin levels. Apoptosis } \\
\text { was suppressed by the extract, which boosted } \\
\text { cytoplasmic Bcl- } 2 \text { expression. }\end{array}$ & (Sobeh et al., 2017) \\
\hline & Anti-nociceptive & $\begin{array}{l}\text { Antinociceptive effects were also shown to be stronger } \\
\text { in the } 400 \mathrm{mg} / \mathrm{kg} \text { extract at } \mathrm{p} \leq 0.05 \text {. The leaves may have } \\
\text { analgesic qualities. }\end{array}$ & (Hishe et al. 2018) \\
\hline & Antinociceptive & $\begin{array}{l}\text { At } 100 \text { and } 200 \mathrm{mg} / \mathrm{kg} \text {, antinociceptive effectiveness was } \\
\text { much higher at P } 0.01 \text {. This study backs up anecdotal } \\
\text { evidence for the usage of the plant in the treatment of } \\
\text { painful illnesses. }\end{array}$ & (Kariuki, 2012) \\
\hline \multirow[t]{3}{*}{ Hibiscus sabdariffa L. } & Antioxidant and anti-inflammatory & $\begin{array}{l}\text { LPS-induced NO production in RAW } 264 \text { is dose- } \\
\text { dependently decreased. The } 7 \text { cell indicates that the } \\
\text { extract may have anti-inflammatory properties. }\end{array}$ & (Zhen et al., 2016) \\
\hline & $\begin{array}{l}\text { Antinociceptive, anti-inflammatory and } \\
\text { antidiarrheal }\end{array}$ & $\begin{array}{l}\text { When compared to a control group of mice, the extract } \\
\text { significantly reduced writhing }(P<0.01) . \text { In xylene- } \\
\text { induced ear oedema model mice, the extract greatly } \\
\text { prevented ear edema production in a dose-dependent } \\
\text { manner as compared to the blank control }(P<0.01) \text {. The } \\
\text { extract showed significant antidiarrheal activity against } \\
\text { castor oil-induced diarrhea in rats at dosages of } 250 \text { and } \\
500 \mathrm{mg} / \mathrm{kg} \text { body weight, lowering the frequency of stools } \\
\text { and increasing the mean latent length }(P<0.01) \text {. }\end{array}$ & (M. K. Ali et al. 2011) \\
\hline & Anti-inflammatory & $\begin{array}{l}\text { The extract dramatically reduced writhing in mice when } \\
\text { compared to a control group }(P<0.01) \text {. When compared }\end{array}$ & (Shen et al. 2016) \\
\hline
\end{tabular}




\begin{tabular}{|c|c|c|c|}
\hline & & $\begin{array}{l}\text { to the blank control in xylene-induced ear edema model } \\
\text { mice, the extract significantly reduced ear edema } \\
\text { development in a dose-dependent manner }(P<0.01) \text {. At } \\
\text { dosages of } 250 \text { and } 500 \mathrm{mg} / \mathrm{kg} \text { body weight, the extract } \\
\text { showed considerable antidiarrheal efficacy against castor } \\
\text { oil-induced diarrhea in rats, reduced the frequency of } \\
\text { stools and increasing the mean latent length }(P<0.01) \text {. }\end{array}$ & \\
\hline \multirow[t]{3}{*}{ Azadirachta indica A. Juss. } & $\begin{array}{l}\text { Anti-inflammatory, pro-apoptotic, and } \\
\text { anti-proliferative. }\end{array}$ & $\begin{array}{l}\text { Our findings reveal that neem extract has a considerable } \\
\text { impact on proinflammatory cell signalling and apoptotic } \\
\text { cell death pathways, allowing us to learn more about the } \\
\text { mechanisms involved. }\end{array}$ & $\begin{array}{l}\text { (Schumacher et al. } \\
\text { 2011) }\end{array}$ \\
\hline & Anti-inflammatory & $\begin{array}{l}\text { Despite the fact that all of the extracts were anti- } \\
\text { inflammatory, chloroform extract was the most effective } \\
\text { against paw edema ( } 53.25 \% \text { inhibition). }\end{array}$ & (Umar et al., 2014) \\
\hline & Anti-nociceptive and anti-inflammatory & $\begin{array}{l}\text { According to the findings, mice given a } 100 \mathrm{mg} \mathrm{kg} 1 \text { dose } \\
\text { of CTCE }+ \text { azadiradione had considerable anti- } \\
\text { nociceptive and anti-inflammatory effects. This study } \\
\text { rationalized tribal people's ethnomedicinal use of the } \\
\text { herb to treat wounds, burns, and injuries. }\end{array}$ & (Ilango et al. 2013) \\
\hline \multirow[t]{3}{*}{ Khaya senegalensis (Desv.) A. Juss. } & Anti-inflammatory and Antinociceptive & $\begin{array}{l}\text { The extract decreases ear edema in mice in a dose- } \\
\text { dependent manner and is significant at } P<0.05 \text {. It also } \\
\text { significantly decreased granuloma formation and paw } \\
\text { edema in rats at } P<0.05 \text {. }\end{array}$ & (Kolawole et al. 2013) \\
\hline & Antioxidant & $\begin{array}{l}\text { Antioxidant capability was found in the plant's leaves, } \\
\text { stem bark, and roots, with } I C_{50} \text { values of } 46,37 \text {, and } 64 \text {, } \\
\text { respectively. }\end{array}$ & (Atawodi et al. 2009) \\
\hline & Chemo preventive on human cancer & $\begin{array}{l}\text { The extract has anti-proliferative, anti-inflammatory, and } \\
\text { pro-apoptotic effects on HT-29, HCT-15, and HCA-7 } \\
\text { cells, according to our findings. }\end{array}$ & $\begin{array}{l}\text { (Androulakis et al., } \\
\text { 2006) }\end{array}$ \\
\hline \multirow[t]{2}{*}{ Ficus sycomorus L. } & Anti-inflammatory & $\begin{array}{l}\text { The findings back up the plant's long history in medicine } \\
\text { and emphasize the value of leaves in the search for new } \\
\text { anti-inflammatory chemicals to treat sickle cell disease. }\end{array}$ & $\begin{array}{l}\text { (Ramdé et al. Guissou, } \\
\text { 2015) }\end{array}$ \\
\hline & Antioxidative and antibacterial & $\begin{array}{l}\text { At } 0.13 \mathrm{mg} / \mathrm{mL} \text { and } 0.25 \mathrm{mg} / \mathrm{mL} \text {, respectively, Ficus } \\
\text { sycomorus latex showed the lowest minimum inhibitory } \\
\text { concentrations (MIC) against Staphylococcus aureus and }\end{array}$ & $\begin{array}{l}\text { (Ramde-Tiendrebeogo } \\
\text { et al., 2012) }\end{array}$ \\
\hline
\end{tabular}




\begin{tabular}{|c|c|c|c|}
\hline & & $\begin{array}{l}\text { Escherichia coli and antiradical activity of an } \mathrm{IC}_{50} \text { of } 9.60 \\
0.02 \mu \mathrm{g} / \mathrm{mL} \text {. }\end{array}$ & \\
\hline & & $\begin{array}{l}\text { Some fractions were shown to be efficient against brine } \\
\text { shrimp larvae and the organisms examined, the most } \\
\text { effective being FS1-1. }\end{array}$ & $\begin{array}{l}\text { (Mudi, Muhammad, } \\
\text { Musa, Datti, 2015) }\end{array}$ \\
\hline \multirow[t]{3}{*}{ Ficus thonningii Blume } & Anti-inflammatory, & $\begin{array}{l}\text { The activity of the extract are comparable to aspirin and } \\
\text { significant at } P<0.05 \text { when compared to Tween } 80 \text {. }\end{array}$ & (Coker et al. 2009) \\
\hline & Antiplasmodial activity & $\begin{array}{l}\text { Both 3D7 and Dd2 did not demonstrate any promising } \\
\text { antiplasmodial activity. With the exception of the } \\
\text { methanolic extract, which had a minor antiplasmodial } \\
\text { action with inhibitory concentration and selectivity index } \\
\text { of } 9.61 \mu \mathrm{g} / \mathrm{mL} \text { and } 11.16 \text {, respectively. }\end{array}$ & $\begin{array}{l}\text { (Koukouikila- } \\
\text { Koussounda et al., } \\
\text { 2013) }\end{array}$ \\
\hline & Antioxidant & $\begin{array}{l}\text { In terms of preventive and curative activities, the extract } \\
\text { demonstrated a non-significant rise in SOD, Catalase, } \\
\text { and glutathione. }\end{array}$ & (Pougoue et al. 2020) \\
\hline \multirow[t]{3}{*}{ Moringa oleifera Lam. } & Antinociceptive and Anti-Inflammatory & $\begin{array}{l}\text { The extract }(10,30 \text {, and } 100 \mathrm{mg} / \mathrm{kg}) \text { demonstrated } \\
\text { significant antinociceptive and inflammatory } \\
\text { effectiveness, which was dose-dependent, in all of the } \\
\text { tests used at } \mathrm{P}<0.05 \text {. }\end{array}$ & (Sulaiman et al., 2008) \\
\hline & Cytotoxic and Anti-Inflammatory & $\begin{array}{l}\text { WSMoL were shown to be non-toxic to mammalian cells; } \\
\text { however, the aqueous seed extract and cmol were found } \\
\text { to be cytotoxic to immune cells, which could explain the } \\
\text { extract's immunosuppressive characteristics. }\end{array}$ & (Araújo et al., 2013) \\
\hline & Antioxidant and anti-inflammatory & $\begin{array}{l}\text { indicated a moderate amount of antioxidant activity. } \\
\text { Plant extract had a high anti-inflammatory impact that } \\
\text { was comparable to diclofenac sodium, a common anti- } \\
\text { inflammatory medicine. }\end{array}$ & $\begin{array}{l}\text { (Alhakmani, Kumar, } \\
\text { Khan, 2013) }\end{array}$ \\
\hline \multirow[t]{2}{*}{ Psidium guajava L. } & Anti-Inflammatory and analgesic & $\begin{array}{l}\text { Inhibited fresh egg albumin-induced acute inflammation } \\
\text { (edema) and thermally and chemically induced } \\
\text { nociceptive pain in rats in a dose-dependent and } \\
\text { significant at } p<0.05-0.001 \text {. }\end{array}$ & (J. Ojewole, 2006) \\
\hline & Anti-Inflammatory & $\begin{array}{l}\text { The } \mathrm{IC}_{50} \text { for leaves and fruit oils were } 3.59 \text { and } 8.11 \\
\mathrm{mg} / \mathrm{mL} \text {, respectively, while the } \mathrm{I}_{50 \mathrm{~S}} \text { for deoxyribose were } \\
12.64 \text { and } 42.78 \mathrm{~g} / \mathrm{L} \text {. }\end{array}$ & (El-Ahmady et al. 2013) \\
\hline
\end{tabular}




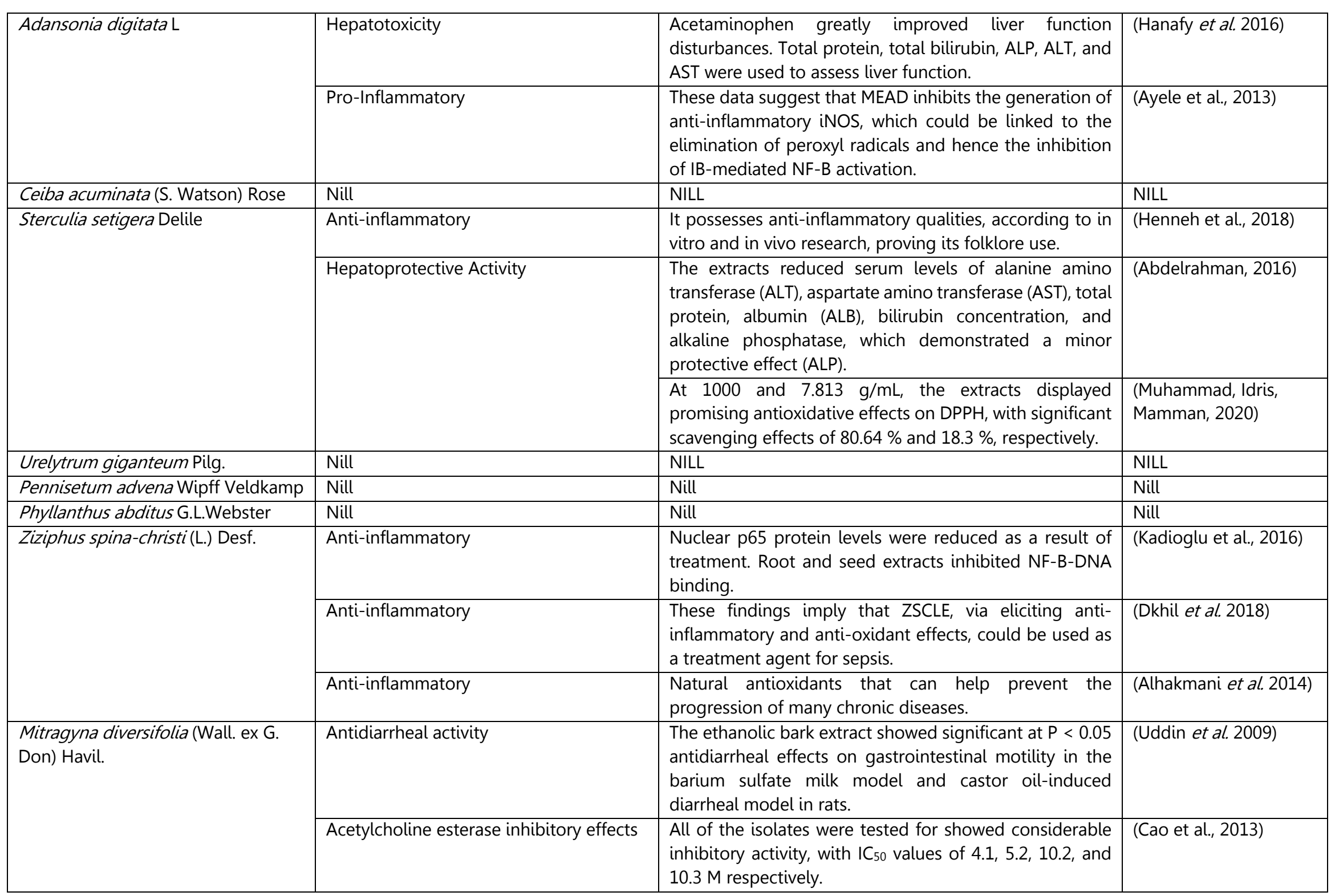




\section{Ethnobotany Research and Applications}

\begin{tabular}{|c|c|c|c|}
\hline & $\begin{array}{l}\text { In-vitro antioxidant and anti- } \\
\text { inflammatory activity }\end{array}$ & $\begin{array}{l}\text { The anti-inflammatory activity of both parts of the plant } \\
\text { extract was comparable to that of the common anti- } \\
\text { inflammatory drug diclofenac. }\end{array}$ & (Alhakmani et al., 2014) \\
\hline Citrus aurantiaca Swingle & Nill & NILL & NILL \\
\hline $\begin{array}{l}\text { Spermacoce suaveolens (G. Mey.) } \\
\text { Kuntze }\end{array}$ & Nill & NILL & NILL \\
\hline \multirow[t]{3}{*}{ Vitellaria paradoxa C.F. Gaertn. } & Biopharmaceutical & $\begin{array}{l}\text { Antioxidant testing demonstrated that maceration } \\
\text { extraction extracts have a significant antioxidant activity. } \\
\text { The enzymatic activity of HAE-derived extracts was found } \\
\text { to be more significant. }\end{array}$ & (Sinan et al., 2020) \\
\hline & Anti-inflammatory & $\begin{array}{l}\text { based on the biological effects of triterpene acetate and } \\
\text { cinnamate esters, has a significant supply of anti- } \\
\text { inflammatory and anti-tumor promoting chemicals }\end{array}$ & (Akihisa et al., 2010) \\
\hline & $\begin{array}{l}\text { Anti-inflammatory and anti-arthritic } \\
\text { activity }\end{array}$ & $\begin{array}{l}\text { After } 1 \text { hour, VPME }(75 \mathrm{mg} / \mathrm{kg}) \text { inhibited carrageenan- } \\
\text { induced inflammation significantly ( } 66.67 \text { percent). }\end{array}$ & (Foyet et al., 2015) \\
\hline
\end{tabular}




\section{Declarations}

List of abbreviations:RFC = Relative Frequency of Citation, FL = Fidelity Level, ICF = Information Consensus Factor, FUC = Field Under Cultivation, AA = Anas Abba, MDB = Mahmoud Dogara Abdulrahman

Ethics approval and consent to participate:The research was conducted with the approval of the Jigawa State Wing of the local traditional herbalist association, a non-governmental organization. Oral consent was obtained from the informants prior to the interview. The informants were fully informed of the study's objectives and willingly agreed to participate.

Consent for publication:Not applicable.

Competing interests:There are no competing interests.

Funding:The study was sponsored by Tertiary Education Trust Fund (TETFund) of Nigeria

Authors contributions:AA Design the research MDA Brought the idea. All authors contributed equally to analysis and drafting the manuscripts.

\section{Acknowledgments}

The authors acknowledged the Tertiary Education Trust Fund (TETFund) as the sponsor of the research through the Institution Based Research, and also the management of the HAFED POLY Kazaure, respondents and traditional holders of Ringim for the support throughout the study period.

\section{Literature Cited}

Abdelrahman TH. 2016. Hepatoprotective activity of ethanolic and ethyl acetate extracts of Sterculia setigera against carbon tetrachloride induced hepatotoxicity in albino rats. Mediterranean Journal of Biosciences 1(3):114119.

Abdulkhaleq L, Assi M, Abdullah R, Zamri-Saad M, Taufiq-Yap Y, Hezmee, M. 2018. The crucial roles of inflammatory mediators in inflammation. A review. Veterinary World 11(5):627.

Abdulrahman MD, Ali AM, Fatihah H, Khandaker MM, Mat N. 2018. Traditional medicinal knowledge of Malays in Terengganu, Peninsular Malaysia. Malayan Nature Journal 70(3):349-364.

Achika J, Ndukwe G, Ayo R. 2016a. Isolation, Characterization and Antimicrobial Activity of 33, 22E-Stigmasta-5, 22dien-3-ol from the Aerial Part of Aeschynomene uniflora E. Mey. Journal of Pharmaceutical Research International 1-8.

Achika J, Ndukwe G, Ayo R. 2016b. Phytochemical screening and antimicrobial studies of aerial part of Aeschynomene uniflora Mey. Indian Chemsitry 2:113-118.

Adejoh IP, Mark-Maria AU, Ojochegbe, AB, Mayowa OJ, Boniface MT. 2019. Effect of Aqueous Leaf Extract of Anogeissus leiocarpus against Experimental Models of Pain and Pyrexia. International Journal of Advanced Biological and Biomedical Research 6(6):181-188.

Adi K, Metowogo K, Mou A, Lawson-Evi P, Eklu-Gadegbeku K, Agbonon A, Gbeassor M. 2013. Evaluation of cardioprotective effects of Parkia biglobosa (Jacq.) Benth Mimosaceae stem bark. Journal of Applied Pharmaceutical Science 3(2):60-64.

Adzu B, Salawu O.A. 2009. Screening Diospyros mespiliformis extract for antimalarial potency. International Journal of Biological and Chemical Sciences 3(2):271-276.

Akhter S, Simom Hasan M, Hasan M, Begum Y. 2018. Investigation of in vivo analgesic and anti-inflammatory activities of methanol extracts of Phyllanthus reticulatus and Mimosa pigra. Phytochemistry 7:2378-2385.

Akihisa T, Kojima N, Kikuchi T, Yasukawa K, Tokuda H, Masters ET, Manosroi J. 2010. Anti-inflammatory and chemopreventive effects of triterpene cinnamates and acetates from shea fat. Journal of Oleo Science 59(6):273280.

Akuodor G, Essien A, David-Oku E, Chilaka K, Akpan J, Ezeokpo B, Ezeonwumelu J. 2013. Gastroprotective effect of the aqueous leaf extract of Guiera senegalensis in albino rats. Asian Pacific Journal of Tropical Medicine,6(10):771775.

Akwu NA, Naidoo Y, Singh M. 2019. Cytogenotoxic and biological evaluation of the aqueous extracts of Grewia lasiocarpa:An Allium cepa assay. South African Journal of Botany 125:371-380. 
Alhakmani F, Khan SA, Ahmad A. 2014. Determination of total phenol, in-vitro antioxidant and anti-inflammatory activity of seeds and fruits of Zizyphus spina-christi grown in Oman. Asian Pacific Journal of Tropical Biomedicine 4:656-660.

Alhakmani F, Kumar S, Khan SA. 2013. Estimation of total phenolic content, in-vitro antioxidant and antiinflammatory activity of flowers of Moringa oleifera. Asian Pacific Hournal of Tropical bBomedicine,3(8):623-627.

Ali MK, Ashraf A, Biswas NN, Karmakar UK, Afroz S. 2011. Antinociceptive, anti-inflammatory and antidiarrheal activities of ethanolic calyx extract of Hibiscus sabdariffa Linn.(Malvaceae) in mice. Zhong xi yi jie he xue baoJournal of Chinese integrative medicine 9(6):626-631.

Ali N, Wurster M, Arnold N, Teichert A, Schmidt J, Lindequist U, Wessjohann L. 2008. Chemical composition and biological activities of essential oils from the oleogum resins of three endemic Soqotraen Boswellia species. Records of Natural Products 2(1):6-12.

Anas A, Ambi A, Zainab M, Jajere U, Umar S. 2018. Evaluation of phytochemicals and anti-inflammatory effects on methanol extracts of Aeschynomene uniflora. Bayero Journal of Pure and Applied Sciences 11(2):32-38.

Androulakis XM, Muga SJ, Chen F, Koita Y, Toure B, Wargovich MJ. 2006. Chemopreventive effects of Khaya senegalensis bark extract on human colorectal cancer. Anticancer Research 26(3B):2397-2405.

Anilkumar M. 2010. Ethnomedicinal plants as anti-inflammatory and analgesic agents. Ethnomedicine: A source of complementary therapeutics 10:267-293.

Araújo LCC, Aguiar JS, Napoleão TH, Mota F, VB, Barros ALS, Moura MC, Paiva PMG. 2013. Evaluation of cytotoxic and anti-inflammatory activities of extracts and lectins from Moringa oleifera seeds. PloS one 8(12):81973. https://doi.org/10.1371/journal.pone.0081973.

Atawodi S, Atawodi J, Pala Y, Idakwo P. 2009. Assessment of the polyphenol profile and antioxidant properties of leaves, stem and root barks of Khaya senegalensis (Desv.) A. Juss. Electronic Journal of Biology,5(4):80-84.

Awan AA, Akhtar T, Ahmed MJ, Murtaza G. 2021. Quantitative ethnobotany of medicinal plants uses in the Jhelum valley, Azad Kashmir, Pakistan. Acta Ecologica Sinica 41(2):88-96.

Awang NA, Ali AM, Abdulrahman MD, Mat N. 2018. Edible bitter mushroom from Besut, Malaysia. Journal of Agrobiotechnology 9(2):70-79.

Awang, N. A., Ali, A. M., Mat, N. (2018). Alternative Medicine from Edible Bitter Plants of Besut, Malaysia. Journal Of Agrobiotechnology 9(2):80-91.

Ayele Y, Kim JA, Park E, Kim YJ, Retta N, Dessie G, Kim HS. 2013. A methanol extract of Adansonia digitata L. leaves inhibits pro-inflammatory iNOS possibly via the inhibition of NF-kB activation. Biomolecules Therapeutics 21(2):146-152.

Barku VY, Boye A, Ayaba S. 2013. Phytochemical screening and assessment of wound healing activity of the leaves of Anogeissus leiocarpus. European Journal of Experimental Biology, 3(4):18-25.

Borquaye LS, Doetse MS, Baah SO, Mensah JA. 2020. Anti-inflammatory and anti-oxidant activities of ethanolic extracts of Tamarindus indica L.(Fabaceae). Cogent Chemistry 6(1):1743403.

Caon XF, Wang JS, Wang XB, Luo J, Wang HY, Kong LY. 2013. Monoterpene indole alkaloids from the stem bark of Mitragyna diversifolia and their acetylcholine esterase inhibitory effects. Phytochemistry 96:389-396.

Chika A, Bello SO. 2010. Antihyperglycaemic activity of aqueous leaf extract of Combretum micranthum (Combretaceae) in normal and alloxan-induced diabetic rats. Journal of Ethnopharmacology 129(1):34-37.

Coker M, Emikpe B, Adeniyi B, Budale B. 2009. The anti-inflammatory potential, heamatological and histological changes induced in rats due to the administration of methanolic extracts of Ficus thonningii leaves. African Journal of Pharmacy and Pharmacology,3(5):273-276.

Compaoré M, Meda RNT, Bakasso S, Vlase L, Kiendrebeogo M. 2016. Antioxidative, anti-inflammatory potentials and phytochemical profile of Commiphora africana (A. Rich.) Engl.(Burseraceae) and Loeseneriella africana (Willd.)(Celastraceae) stem leaves extracts. Asian Pacific Journal of Tropical Biomedicine 6(8):665-670. 
Dasgupta B, Kalita JC, Chowdhury A, Kotoky J. 2012. Hepatoprotective activity of Nelsonia canescens (Lam.) Spreng on acute hepatotoxicity induced by paracetamol. International Journal of Pharmaceutical and Pharmacoilogical Science 4(1):107-112.

David OM, Olanlokun JO, Owoniyi BE, Ayeni M, Ebenezer O, Koorbanally NA. 2021. Studies on the mitochondrial, immunological and inflammatory effects of solvent fractions of Diospyros mespiliformis Hochst in Plasmodium berghei-infected mice. Scientific Reports 11(1):1-15.

Divya R, Venkatalakshmi P, Vadivel V, Brindha P. 2016. In vitro studies on the biological activities of flowers of banana (Musa Paradisiaca L.). Der Pharmacia Lettre 10:238-246.

Dkhil MA, Al-Quraishy S, Moneim AEA. 2018. Ziziphus spina-christi leaf extract pretreatment inhibits liver and spleen injury in a mouse model of sepsis via anti-oxidant and anti-inflammatory effects. Inflammopharmacology,26(3):779791.

Durugbo E, Oyetoran B, Oyejide N. 2012. Vegetation inventory of the Redemption Camp, Ogun State, Nigeria; Evaluation of medicinal plant resources and strategies for Conservation. Journal of Biological Sciences 12(1):34-42.

El-Ahmady SH, Ashour ML, Wink M. 2013. Chemical composition and anti-inflammatory activity of the essential oils of Psidium guajava fruits and leaves. Journal of Essential Oil Research 25(6):475-481.

Eltayeb I. M, Ali HAR. 2016. Antioxidant Activity and Cytotoxic Studies of Anogeissus leiocarpous Root, Leaf and Stem. American Journal of Research Communication 4(3):52-67.

Ezekiel I, Mabrouk M, Ayo J. 2010. Study of the effect of hydro-ethanolic extract of Commiphora africana (stembark) on inflammation and pain in rodents. Asian Journal of Medical Sciences 2(3):81-84.

Fernandes, J. C., Collaborators, G. C. o. D. (2018). Erratum:Global, regional, and national age-sex-specific mortality for 282 causes of death in 195 countries and territories, 1980-2017:a systematic analysis for the Global Burden of Disease Study 2017 (The Lancet (2018) 392 (10159)(1736-1788)(S0140673618322037)(10.1016/S0140-6736 (18) 32203-7)). The Lancet 392(10160), 2170-2170.

Foyet HS, Tsala DE, Bodo JZE, Carine AN, Heroyne LT, Oben EK. 2015. Anti-inflammatory and anti-arthritic activity of a methanol extract from Vitellaria paradoxa stem bark. Pharmacognosy Research 7(4):367-377.

Fredotović Ž, Šprung M, Soldo B, Ljubenkov I, Budić-Leto I, Bilušić T, Puizina J. 2017. Chemical composition and biological activity of Allium cepa L. and Allium x cornutum (Clementi ex Visiani 1842) methanolic extracts. Molecules 22(3):448. doi: 10.3390/molecules22030448.

Gammulle A, Ratnasooriya W, Jayakody J, Fernando C, Kanatiwela C, Udagama PV. 2012. Thrombocytosis and antiinflammatory properties, and toxicological evaluation of Carica papaya mature leaf concentrate in a murine model. Online International Journal of Medicinal Plants Research 1 (2):21-30.

Goji A, Dikko A, Bakari A, Mohammed A, Tanko Y. 2009. Evaluation of the Effect of Aqueous-ethanolic Stem Bark Extract of Commiphora Africana on Blood Glucose Levels of Alloxan Induced Diabetic Wistar Rats. Asian Journal of Medical Sciences,1(2):18-21.

Hanafy A, Aldawsari HM, Badr JM, Ibrahim AK, Abdel-Hady E-S. 2016. Evaluation of hepatoprotective activity of Adansonia digitata extract on acetaminophen-induced hepatotoxicity in rats. Evidence-Based Complementary and Alternative Medicine. doi: 10.1155/2016/4579149.

Henneh IT, Akrofi R, Ameyaw EO, Konja D, Owusu G, Abane B, Tayman F. 2018. Stem bark extract of Sterculia setigera delile exhibits anti-inflammatory properties through membrane stabilization, inhibition of protein denaturation and prostaglandin e2 activity. Journal of Pharmaceutical Research International,1-11.

Hishe HZ, Ambech TA, Hiben MG, Fanta BS. 2018. Anti-nociceptive effect of methanol extract of leaves of Senna singueana in mice. Journal of Ethnopharmacolog, 49-53.

Idris A, Aliyu A, Oyewale A. 2019. Phytochemical screening and antibacterial activity of Centaurea senegalensis growing in Nigeria. Journal of Applied Sciences and Environmental Management 23(6):1087-1092.

Ilango K, Maharajan G, Narasimhan S. 2013. Anti-nociceptive and anti-inflammatory activities of Azadirachta indica fruit skin extract and its isolated constituent azadiradione. Natural Product Research 27(16):1463-1467. 
Iliya HA, Woode E. 2014. Evaluation of analgesic property of petroleum ether/ethyl acetate stem bark extract and fractions of Maerua angolensis in murine models of pain. Journal of Applied Pharmaceutical Science 5(02):91-102.

Jadav SP, Patel NH, Shah TG, Gajera MV, Trivedi HR, Shah BK. 2010. Comparison of anti-inflammatory activity of serratiopeptidase and diclofenac in albino rats. Journal of Pharmacology Pharmacotherapeutics 1(2):116-117.

Jigam AA, Akanya HO, Dauda BE, Ogbadoyi EO. 2011. Antiplasmodial, analgesic and anti-inflammatory effects of crude Guiera senegalensis Gmel (Combretaceae) leaf extracts in mice infected with Plasmodium berghei. Journal of Pharmacognosy and Phytotherapy 3(10):150-154.

Kadioglu O, Jacob S, Bohnert S, Naß J, Saeed ME, Khalid H, Efferth T. 2016. Evaluating ancient Egyptian prescriptions today:anti-inflammatory activity of Ziziphus spina-christi. Phytomedicine 23(3):293-306.

Kamau J, Nthiga P, Mwonjoria J, Ngeranwa J, Ngugi M. 2016. Anti-inflammatory activity of methanolic leaf extract of Kigelia africana (Lam.) Benth and stem bark extract of Acacia hockii De Wild in Mice. Journal of Development in Drugs 5(2):1-8.

Kamau J, Nthiga P, Safari V, Njagi S, Mwonjoria J, Ngugi P, Ngeranwa J. 2016. Antipyretic Properties of Methanol Stem Bark Extracts of Acacia hockii De Wil d and Kigelia africana (Lam) Benth in Wistar Rats. Jpurmal of Pharmacognoscy nd Natural Products 2(118):2472-0992.100011.

Kankara SS, Ibrahim MH, Mustafa M, Go R. 2015. Ethnobotanical survey of medicinal plants used for traditional maternal healthcare in Katsina state, Nigeria. South African Journal of Botany 97:165-175.

Kankara SS, Isah AB, Bello A, Ahmed A, Lawal U. 2018. Medicinal plants used for the management of hepatic ailments in Katsina State, Nigeria. Journal of Medicinal Plants Research 12(24):375-386.

Kariuki HN. 2012. Antinocieptive activity of the root extracts of Rhus natalensis Kraus and Senna singueana. Phytopharmacology.

Kim H, Castellon-Chicas MJ, Arbizu S, Talcott ST, Drury NL, Smith S, Mertens SU. 2021. Mango (Mangifera indica L.) Polyphenols:Anti-Inflammatory Intestinal Microbial Health Benefits, and Associated Mechanisms of Actions. Molecules 26(9):2- 15.

Kolawole O, Akiibinu M, Ayankunle A, Awe E. 2013. Evaluation of anti-inflammatory and antinociceptive potentials of Khaya senegalensis A. Juss (Meliaceae) stem bark aqueous extract. Journal of Advances in Medicine and Medical Research,216-229.

Koman SR, Kpan WB, Yao K, Outtara D. 2021. Medicinal uses of plants by traditional birth attendants to facilitate childbirth among Djimini women in Dabakala (Center-North of Côte d'Ivoire). Ethnobotany Research and Applications 21:1-12.

Kouadio F, Kanko C, Juge M, Grimaud N, Jean A, N'guessan Y, Petit J. 2000. Analgesic and antiinflammatory activities of an extract from Parkia biglobosa used in traditional medicine in the Ivory Coast. Phytotherapy Research:An International Journal Devoted to Pharmacological and Toxicological Evaluation of Natural Product Derivatives,14(8):635-637.

Koukouikila-Koussounda F, Abenab A, Nzounganic A, Mombouli J-V, Ouambae J, Kunf J, Ntoumia F. 2013. In vitro evaluation of antiplasmodial activity of extracts of Acanthospermum hispidum DC (Asteraceae) and Ficus thonningii blume (Moraceae), two plants used in traditional medicine in the Republic of Congo. African Journal of Traditional, Complementary and Alternative Medicines,10(2):270-276.

Kpemissi M, Eklu-Gadegbeku K, Veerapur VP, Negru M, Taulescu M, Chandramohan V, Suhas DS. 2019. Nephroprotective activity of Combretum micranthum G. Don in cisplatin induced nephrotoxicity in rats:In-vitro, invivo and in-silico experiments. Biomedicine Pharmacotherapy. doi: 10.1016/j.biopha.2019.108961.

Lagnika L, Tchatchedre M, Amoussa AMO, Latoundji K, Sanni A. 2016. Phytochemical assessment, in vitro antimicrobial and antioxidant activities of Acacia hockii De Wild. BioMedicine 3(1):1-8.

Mahmoud AD, Labaran I, Yunusa A. 2020. Ethnobotany of medicinal plants with antimalarial potential in Northern Nigeria. Ethnobotany Research and Applications 19:1-8. 
Meda N, Bangou M, Bakasso S, Millogo-Rasolodimby J, Nacoulma O. 2013. Antioxidant activity of phenolic and flavonoid fractions of Cleome gynandra and Maerua angolensis of Burkina Faso. Journal of Applied Pharmaceutical Science,3(2):36.

Mohaddesi B, Ashok B, Acharya R, Shukla VJ. 2015. Anti-inflammatory activity of Nelsonia canescens (Lam) Spreng. root in albino rats. The Journal of Phytopharmacology 4(2):68-72

Mothana RA, Lindequist U. 2005. Antimicrobial activity of some medicinal plants of the island Soqotra. Journal of Ethnopharmacology 96(1-2):177-181.

Mudi S, Muhammad A, Musa J, Datti Y. 2015. Phytochemical screening and antimicrobial activity of leaves and fruits extract of Ficus sycomorus. ChemSearch Journal 6(1):62-67.

Muhammad A, Idris MM, Mamman A. 2020. In vitro Screening of Potential Antioxidative and Toxicity of the Stembark Extracts from Sterculia setigera Del. Algerian Journal of Natural Products,8(2):774-779.

Nabèrè O, Alphonsine RT, Samson G, Zaib S, Roland MNT, Kiessoun K, Martin K. 2019. Cytotoxicity Potential of Nelsonia canescens (Lam.) Spreng Extracts against Cervical Cancer Cell Lines. Saudi Journal of Biomedical Research 4(12):439-443.

Nam J, Seol D-W, Lee C-G, Wee G, Yang S, Pan C-H. 2021. Obtusifolin, an Anthraquinone Extracted from Senna obtusifolia (L.) HS Irwin Barneby, Reduces Inflammation in a Mouse Osteoarthritis Model. Pharmaceuticals 14(3):29.

Namsa ND, Tag H, Mandal M, Kalita P, Das A. 2009. An ethnobotanical study of traditional anti-inflammatory plants used by the Lohit community of Arunachal Pradesh, India. Journal of Ethnopharmacology,125(2):234-245.

Nwagu TN, Ugwuodo CJ, Onwosi, CO, Inyima O, Uchendu OC, Akpuru C. 2020. Evaluation of the probiotic attributes of Bacillus strains isolated from traditional fermented African locust bean seeds (Parkia biglobosa), "daddawa". Annals of Microbiology, 70(1):1-15.

Ojewole J. 2006. Antiinflammatory and analgesic effects of Psidium guajava Linn.(Myrtaceae) leaf aqueous extract in rats and mice. Methods and Findings in Experimental and Clinical Pharmacology,28(7):441-446.

Ojewole JA. 2003. Evaluation of the anti-inflammatory properties of Sclerocarya birrea (A. Rich.) Hochst.(family:Anacardiaceae) stem-bark extracts in rats. Journal of Ethnopharmacology 85(2-3):217-220.

Olajide OA, Makinde JM, Okpako DT. 2003. Evaluation of the anti-inflammatory property of the extract of Combretum micranthum G. Don (Combretaceae). Inflammopharmacology 11(3):293-298.

Olanlokun JO, Bodede O, Prinsloo G, Olorunsogo OO. 2021. Comparative antimalarial, toxicity and mito-protective effects of Diospyros mespiliformis Hochst. ex A. DC. and Mondia whitei (Hook. f.) Skeels on Plasmodium berghei infection in mice. Journal of Ethnopharmacology. doi: 10.1016/j.jep.2020.113585.

Ouattara N, Meda R, N.-T, Hilou A, Guenné S, Konaté K, Coulibaly AY, Nacoulma OG. 2013. Anti-acetylcholinesterase and antioxidant activities and HPLC-MS analysis of polyphenol from extracts of Nelsonia canescens (Lam.) Spreng. Asian Pacific Journal of Tropical Disease 3(5):382-388.

Owoyele BV, Adebukola OM, Funmilayo AA, Soladoye AO. 2008. Anti-inflammatory activities of ethanolic extract of Carica papaya leaves. Inflammopharmacology, 16(4):168-173.

Pahwa R, Goyal A, Bansal P, Jialal I 2020. Chronic Inflammation, in StatPearls [Internet]. StatPearls Publishing

Paré D, N'do JYP, Ouédraogo V, Ouoba AMA, Hilou A. 2021. Sclerocarya birrea (A. Rich.) Hochst. and Sterculia setigera Del. extracts as a potential inhibitor of Pseudomonas aeruginosa PAO1 and Chromobacterium violaceum CV026 virulence factors to combat bacterial pathogenicity. World Journal of Biology Pharmacy and Health Sciences,5(1):009-018.

Parvez MK, Al-Dosari MS, Arbab AH, Al-Rehaily AJ, Abdelwahid MA. 2020. Bioassay-guided isolation of anti-hepatitis B virus flavonoid myricetin-3-O-rhamnoside along with quercetin from Guiera senegalensis leaves. Saudi Pharmaceutical Journal 28(5):550-559. 
Pougoue J, Fokunang E, Beringyuy E, Fokunang C. 2020. Evaluation of antioxidant properties of secondary metabolites in aqueous extracts of Ficus thonningii blume tested on wistar rats. Journal of Analytical Pharmaceutical Research 9 (1):27-35.

Pungle R, Tambe A, More A, Kharat A. 2018. Anti-inflammatory and antioxidant potentiality of Solanum xanthocarpum. African Journal of Biotechnology,17(37):1188-1195.

Ramde TA, Tibiri A, Hilou A, Lompo M, Millogo-Kone H, Nacoulma OG., Guissou IP. 2012. Antioxidative and antibacterial activities of phenolic compounds from Ficus sur Forssk. and Ficus sycomorus L.(Moraceae):Potential for sickle cell disease treatment in Burkina Faso. International Journal of Biological and Chemical Sciences 6 (1):328336.

Ramdé-Tiendrébéogo A, Ouédraogo N, Tibiri A, Nacoulma OG, Guissou IP. 2015. Anti-inflammatory Activities of Total Leaf Extracts of Ficus sycomorus L.(Moraceae) used in Traditional Medicine in the Treatment of Sickle Cell Disease. Journal of Young pharmacists 7(4):359-367.

RamPravinKumar M, Dhananjayan K. 2021. Peripheral arterial disease:Effects of ethanolic extracts of seed kernels of Mango (Mangifera indica. L) on acute hind limb ischemia-reperfusion injury in Diabetic Rats. Journal of Traditional and Complementary Medicine. doi: 10.1016/j.jtcme.2021.05.004.

Rankin JA. 2004. Biological mediators of acute inflammation. AACN Advanced Critical Care 15(1):3-17.

Rivera DG, Hernández I, Merino N, Luque Y, Álvarez A, Martín Y, Delgado R. 2011. Mangifera indica L. extract (Vimang) and mangiferin reduce the airway inflammation and Th2 cytokines in murine model of allergic asthma. Journal of Pharmacy and Pharmacology 63 (10):1336-1345.

Russo D, Miglionico R, Carmosino M, Bisaccia F, Andrade PB, Valentão P, Armentano MF. 2018. A comparative study on phytochemical profiles and biological activities of Sclerocarya birrea (A. Rich.) Hochst leaf and bark extracts. International Journal of Molecular Sciences 19 (1):2-14.

Sagnia B, Fedeli D, Casetti R, Montesano C, Falcioni G, Colizzi V. 2014. Antioxidant and anti-inflammatory activities of extracts from Cassia alata, Eleusine indica, Eremomastax speciosa, Carica papaya and Polyscias fulva medicinal plants collected in Cameroon. PloS one, 9(8). doi: 10.1371/journal.pone.0103999.

Sangiovanni E, Dell'Agli M. 2020. Anti-inflammatory activity of plant polyphenols. In:Multidisciplinary Digital Publishing Institute.8(3):1-5.

Schumacher M, Cerella C, Reuter S, Dicato M, Diederich M. 2011. Anti-inflammatory, pro-apoptotic, and antiproliferative effects of a methanolic neem Azadirachta indica leaf extract are mediated via modulation of the nuclear factor-кB pathway. Genes nutrition, 6(2):149-160.

Shen CY, Zhang TT, Zhang WL, Jiang JG. 2016. Anti-inflammatory activities of essential oil isolated from the calyx of Hibiscus sabdariffa L. Food function 7(10):4451-4459.

Shorinwa OA, Ubele C, Ukwueze SE. 2015. Evaluation of the analgesic and anti-inflammatory activities of ethanol extract of the root of Mimosa pigra Linn (Fabaceae) in albino rats. International Journal of Pharmacy and Pharmaceutical Sciences 7:376-379.

Sinan KI, Martinović LS, Peršurić Ž, Pavelić SK, Etienne OK, Mahomoodally MF, Zengin G. 2020. Novel insights into the biopharmaceutical potential, comparative phytochemical analysis and multivariate analysis of different extracts of shea butter tree-Vitellaria paradoxa CF Gaertn. Process Biochemistry 98:65-75.

Sobeh M, Mahmoud MF, Abdelfattah MA, Cheng H, El-Shazly AM, Wink M. 2018. A proanthocyanidin-rich extract from Cassia abbreviata exhibits antioxidant and hepatoprotective activities in vivo. Journal of Ethnopharmacology 213:38-47.

Sobeh M, Mahmoud MF, Hasan RA, Cheng H, El-Shazly AM, Wink M. 2017. Senna singueana:Antioxidant, hepatoprotective, antiapoptotic properties and phytochemical profiling of a methanol bark extract. Molecules,22 (9):2-15.

Sonibare MA, Abegunde R. 2012. Ethnobotanical study of medicinal plants used by the Laniba village people in South Western Nigeria. African Journal of Pharmacy and Pharmacology 6(24):1726-1732. 
Sulaiman MR, Zakaria Z, Bujarimin A, Somchit M, Israf D, Moin S. 2008. Evaluation of Moringa oleifera aqueous extract for antinociceptive and anti-inflammatory activities in animal models. Pharmaceutical Biology 46(12):838845.

Suralkar AA, Rodge KN, Kamble RD, Maske KS. 2012. Evaluation of anti-inflammatory and analgesic activities of Tamarindus indica seeds. International Journal of Pharmaceutical Sciences and Drug Research 4(3):213-217.

Takahashi M, Shibamoto T. 2008. Chemical compositions and antioxidant/anti-inflammatory activities of steam distillate from freeze-dried onion Allium cepa L. sprout. Journal of Agricultural and Food Chemistry 56(22):1046210467.

Toma TT, Rahman S, Jahan S, Haque M, Agarwala B, Shelley MMR, Rahmatullah M. 2012. Antihyperglycemic and antinociceptive activity of Fabaceae family plants-an evaluation of Mimosa pigra L. leaves. Advances in Natural and Applied Sciences 6(8):1552-1557.

Uddin SB, Mahabub UZM, Akter R, Ahmed NU. 2009. Antidiarrheal activity of ethanolic bark extract of Mitragyna diversifolia. Bangladesh Journal of Pharmacology 4(2):144-146.

Udupa A, Rathnakar U, Udupa S. 2007. Anti-inflammatory, anti-pyretic and analgesic effects of Tamarindus indica. Indian Drugs 44(6):466-470.

Umar MI, Asmawi MZ, Sadikun A, Abdul Majid A, Atangwho IJ, Khadeer Ahamed MB, Ahmad A. 2014. Multiconstituent synergism is responsible for anti-inflammatory effect of Azadirachta indica leaf extract. Pharmaceutical Biology 52(11):1411-1422.

Zakariya AM, Adamu A, Nuhu A, Kiri IZ. 2021. Assessment of indigenous knowledge on medicinal plants used in the management of malaria in Kafin Hausa, north-western Nigeria. Ethnobotany Research and Applications 22:118.

Zhen J, Villani TS, Guo Y, Qi Y, Chin K, Pan M-H, Wu Q. 2016. Phytochemistry, antioxidant capacity, total phenolic content and anti-inflammatory activity of Hibiscus sabdariffa leaves. Food Chemistry 190:673-680. 